\title{
Village women organize: The Mraru Bus Service
}

Jill Kneerim

Follow this and additional works at: https://knowledgecommons.popcouncil.org/departments_sbsr-pgy

Part of the Family, Life Course, and Society Commons, Gender and Sexuality Commons, International Public Health Commons, and the Regional Economics Commons How does access to this work benefit you? Let us know!

\section{Recommended Citation}

Kneerim, Jill. 1980. "Village women organize: The Mraru Bus Service," SEEDS no. 1. New York: Population Council. 


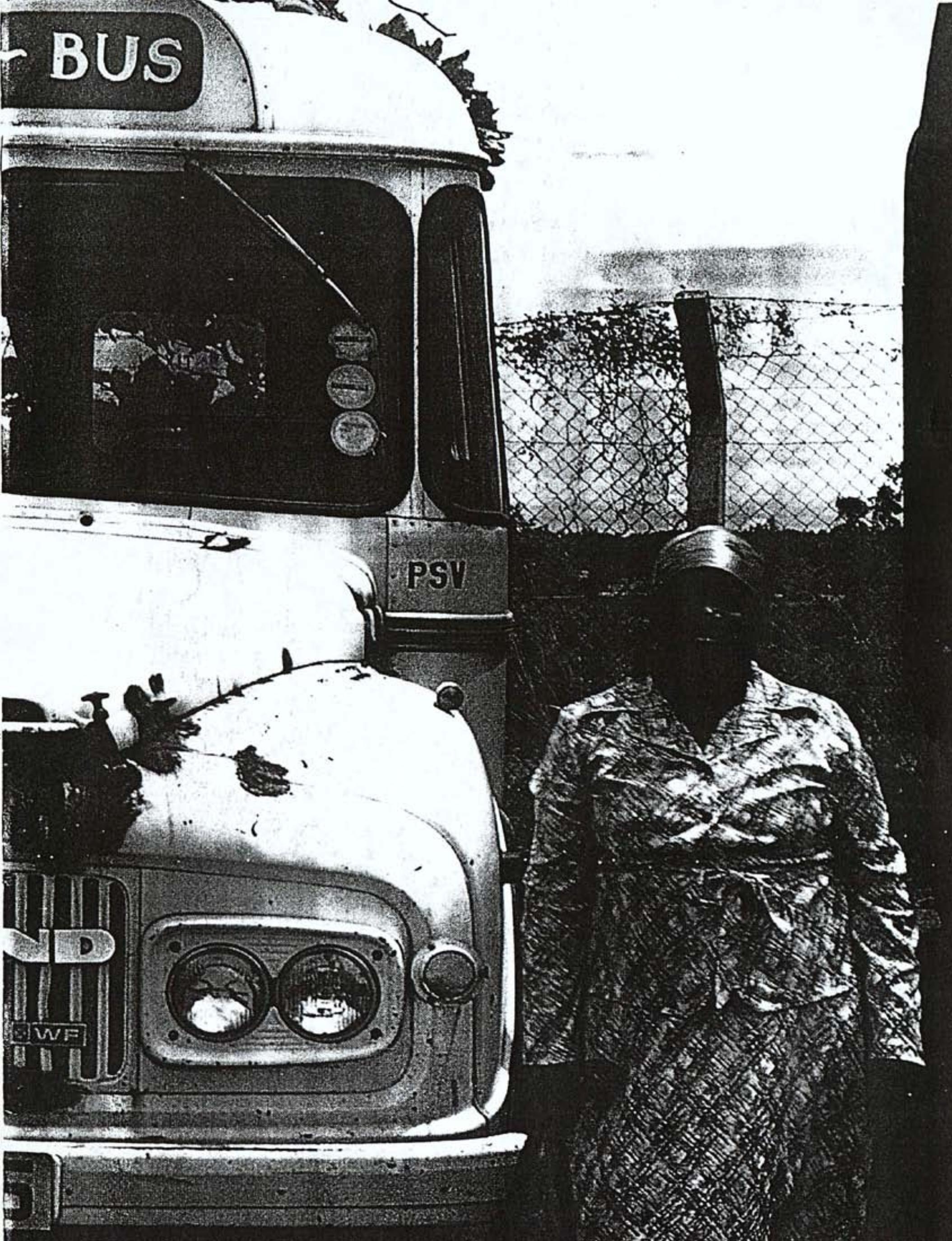


SEEDS is a new pamphlet series developed to meet requests from all over the world for information about innovative and practical program ideas developed by and for low income women. The pamphlets are designed as a means to share information and spark new projects based on the positive experiences of women who are working to help themselyes and other women improve their economic status. The projects described in this and future issues of SEEDS have been selected because they provide women with a cash income, involve women in decision-making as well as earning, are based on sound economic criteria, and are working successfully to overcome obstacles commonly encountered. The reports are not meant to be prescriptive, since every development effort will face somewhat different problems and resources. Rather, they have been written to describe the history of an idea and its implementation in the hope that the lessons learned can be useful in a variety of settings. They are also being written to bring to the attention of those in decision-making positions the fact that incomegenerating projects for and by women are viable and have important roles to play in development.

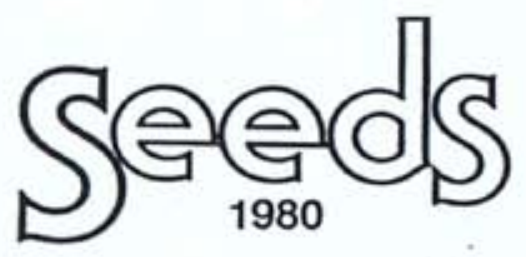




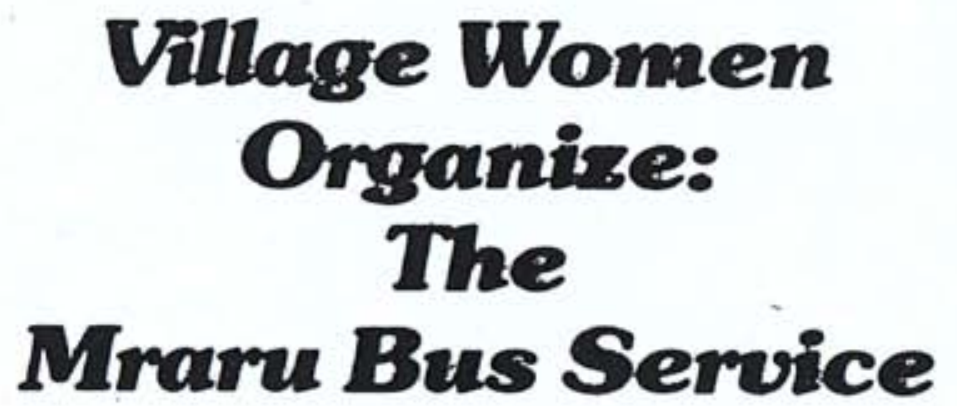

Story and Photographs by Jill Kneerien

\section{Introduction}

The Mraru Women's Group, like many community women's organizations around the world, is an example of a deeply-rooted tradition of association and self-help among women. In 1971 the group began to gather its resources to solve a common problem-transportation. They raised money, bought a bus and began a public transport service that made money. Now they are faced with other difficult questions such as reinvesting profits, serving members' broader needs, and maintaining a strong economic base. The Mraru Women's Group has shown unusual creativity and persistence in identifying common needs and organizing to meet them. They have also demonstrated that a small, private organization with few resources can effectively call on the skills and resources of other agencies, both public and private, to help them achieve their goals, while remaining independent and selfreliant. It is hoped that their experience may be an inspiration to other such groups and that other women will be able to profit from the lessons learned by the women of Mraru. 


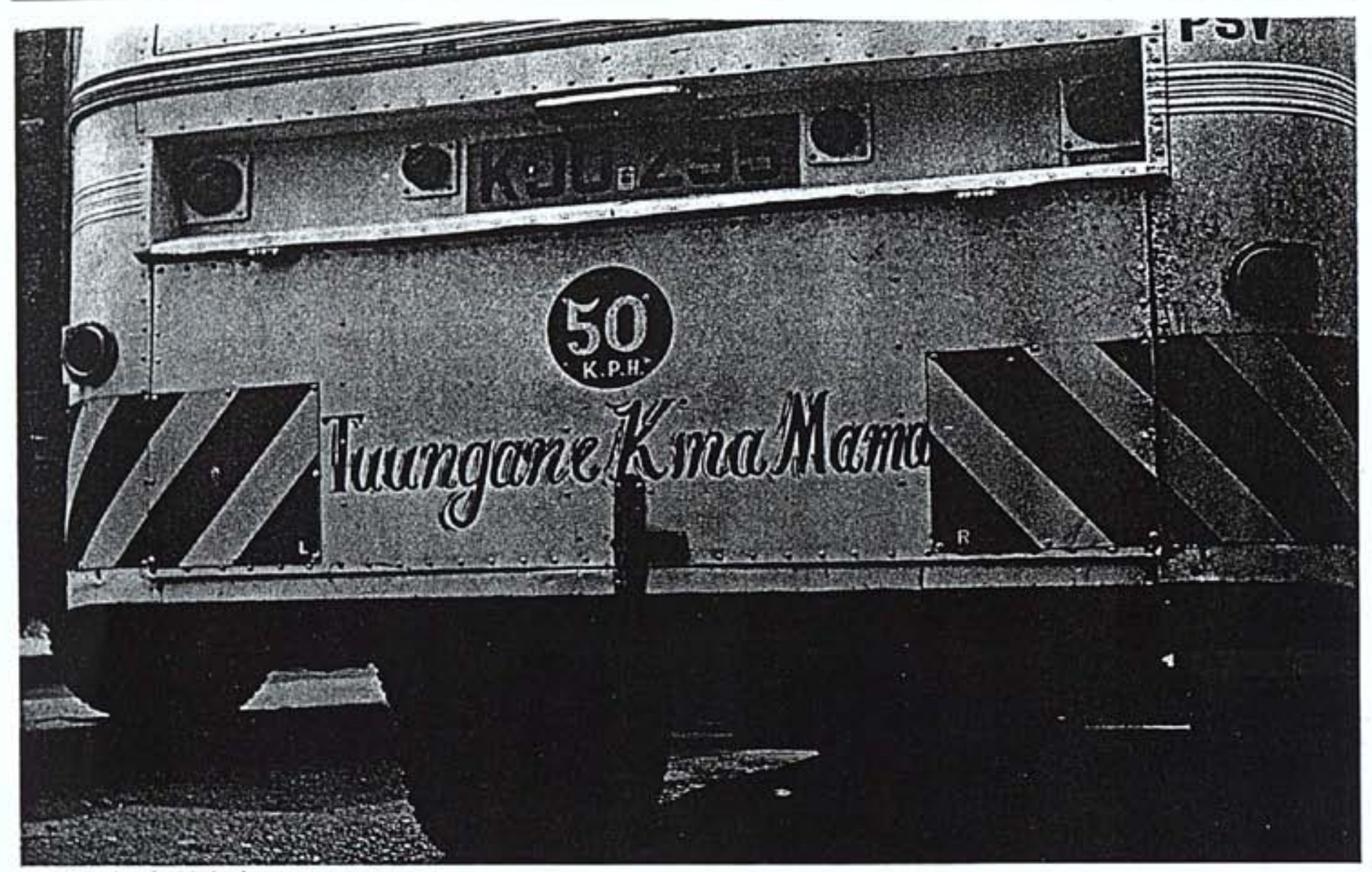

Women, Let's Unite!

The women in Mraru got angry one year. The nearest market center for this cluster of eight small villages in the Taita Hills of Kenya was the town of Voi, about 12 kilometers away. You can't carry heavy goods to market or a sick child to the clinic on foot over that distance. There aren't many buses to Voi, and almost all are fully loaded by the time they reach Mraru. If there is any space, it goes to the men, not women. Men first: that is the tradition in the countryside of Kenya, and for women, the tradition is to resign themselves to it. But in 1971, the Mraru women decided to do something else. They decided to buy their own bus.

This sounds like an unusual decision, and it was. How could a handful of rural women with no regular incomes, in a country where few women own property, collect enough money for the down payment on a vehicle and then persuade a bank to lend them the balance? It sounded like a daydream. But six years later, with the bus paid for and running a regular route to Voi every day, the Mraru Women's Group had declared a dividend to its early shareholders and was building a retail shop with its profits.
The Taita women in Mraru are not wealthy or well educated or in any other way noticeably different from village women in other parts of Kenya, or even other parts of the world. Virtually all of them raise large families and produce the family's food in shambas, small plots owned by their husbands. They earn some cash by selling maize or cassava root or goats they have bred (when they can get these goods to market) or from trade, buying small quantities of goods at wholesale which they can sell at retail. In a good year, a typical woman in Mraru may make 1,000 Kenya shillings, about US $\$ 130$, which she usually spends on the family: school fees for the children, the food she doesn't grow herself, corrugated roofing for the house.

\section{The Mraru Women's Group}

In 1970, forty-seven women in the several villages of Mraru joined together to form a club affiliated with the national women's organization Maendeleo ya Wanawake ("Women's Progress" in Swahili). They chose as chairperson Mrs. Eva Mwaluma, a member of the Taita/Taveta County Council at the district headquarters in Wundanyi. 


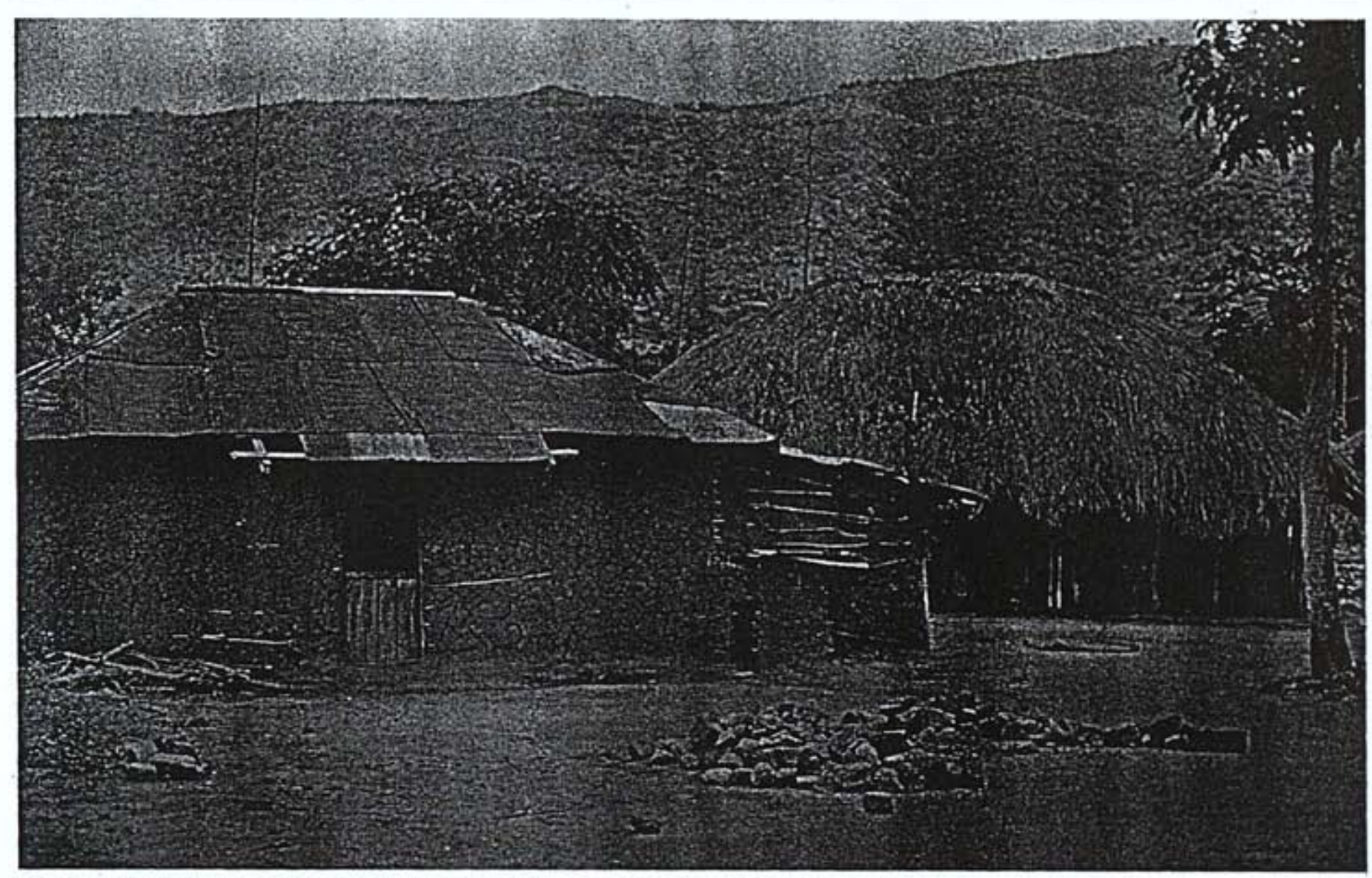

Wattle-and-daub houses in Mraru, with hammered tin-can roofing and thatch.

The Mraru group met regularly to learn about crafts and homemaking and to talk over their problems. Eventually, one of the problems they talked about was transportation into Voi. A year of drought was making trading particularly important, yet all of them were having trouble getting to the market in Voi. There had even been some desperate cases of women or babies lost in childbirth because there was no way to get to Voi's maternity clinic. The women decided that the best solution to this problem was to buy their own bus.

In rural Kenya, most transportation is provided by private entrepreneurs. Even the country buses - dented, patched, and repainted old products of Mercedes Benz and British Leyland that toil along the country roads from town to town - are private property, not a publicly run service. Virtually every route they take, as well as many they never get to, is also run by smaller conveyances called matatus. These jitneys sporting flamboyant slogans in Swahili are a familiar sight all over the country, hurtling along loaded to twice their stated capacity with the conductor hanging off the back step shouting out his destination.

In August, 1971 the Mraru women started saving for their bus. They agreed that, over time, each member should contribute at least 200 shillings (about \$27), which would therefore be the value of one share. Like many other groups of women in Kenya who form savings societies, they met every month, and each member contributed what she could afford. Those without money brought eggs, hens, fruits anything of value. These contributions were given a cash value and entered in the record book along with cash payments for the month. At one typical meeting, they collected 793 shillings. Next day, the funds were deposited in the Mraru Maendeleo ya Wanawake savings account at the post office in Voi.

Small things accumulate. By 1973 , they had saved 27,000 shillings $(\$ 3,600)$. That was sufficient capital for Mrs. Mwaluma to go to Mombasa, some $\mathbf{1 7 0}$ kilometers away, to place an order for a bus with the Cooper Motor Corporation. This was the beginning of a long process. Construction of the bus body would take time and could not begin until an order was placed. The Cooper branch manager figured out the costs. The bus, an 11,760-pound British Leyland diesel with an aluminum body and 


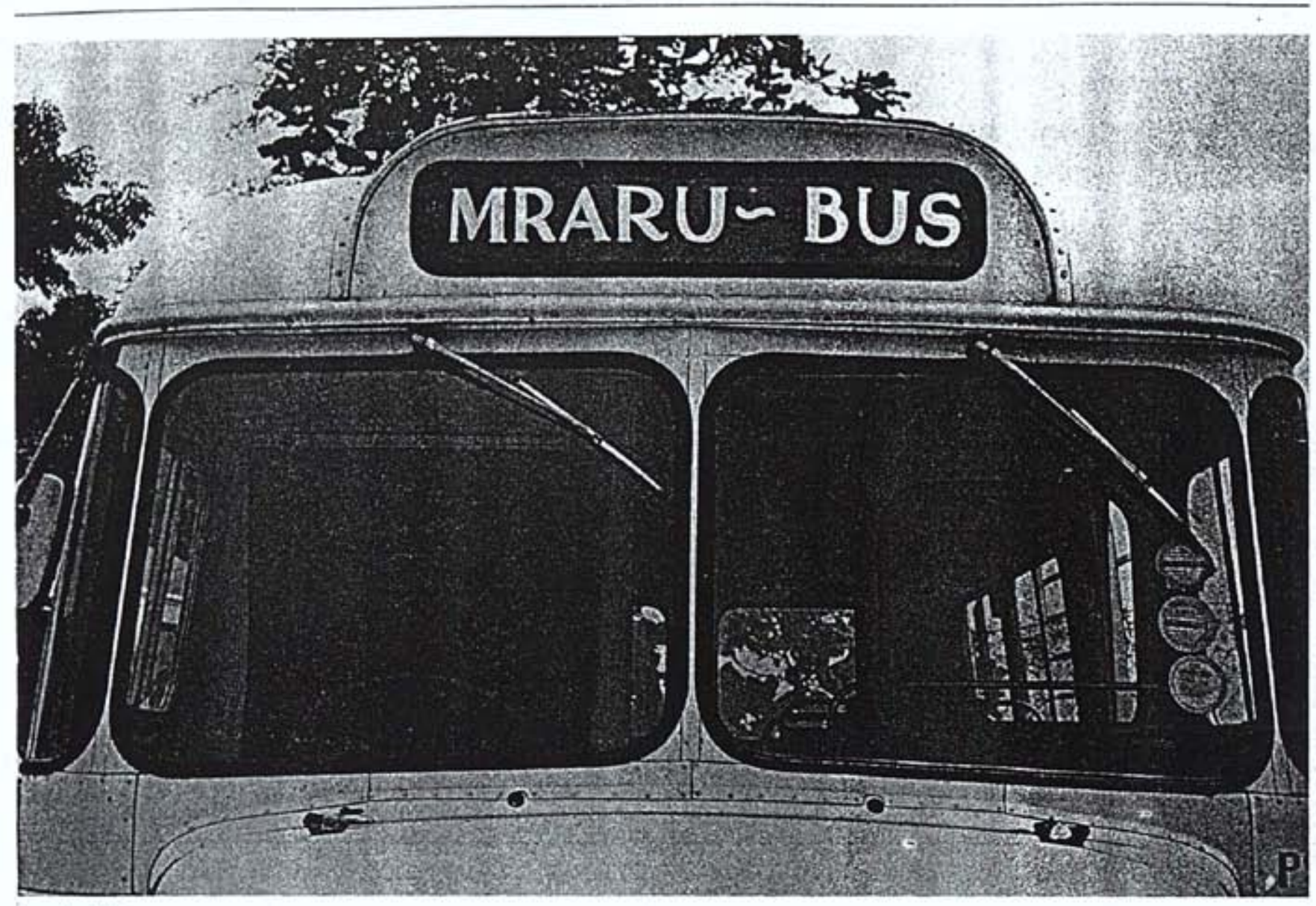

Inspiration

seating for 21 passengers, would cost 111,780 shillings, including finance costs. Cooper would need a down payment of 47,800 to release the bus. The group would have to raise 21,000 shillings more just for the down payment. In addition, they would have to get a very substantial loan to cover the remainder of the purchase price, and their only collateral was their determination to succeed. The bus itself would not be considered collateral because rough, overcrowded roads and reckless drivers make vehicles too vulnerable.

Nonetheless, the group's spirits were high. It seemed possible that their dream could become reality. Some of the more skeptical members now began to deliver more money, and the women held fundraisings to collect donations from outsiders. (Public fund-raisings - called harambees after the national motto meaning "join together" - are a widespread, popular tradition in Kenya begun by the first president, Jomo Kenyatta.) More women joined, and the possibility of obtaining a loan began to improve. A government social services worker in Mombasa lobbied with the Cooper Motor Corporation and persuaded its managers that this group was worth taking a chance on. The company was able to obtain a commitment from National Industrial Credit (East Africa) Limited in Nairobi to lend the Mraru women over half the purchase price on the strength of the Cooper manager's sworn assurance that if any payment was late, he personally would go to Mraru to collect it.

By early 1975 the bus was in the warehouse in Mombasa and ready to go. According to size, weight, and capacity, it was a matatu, but it appeared considerably more imposing than most matatus. It looked like a scaled-down, brand new country bus, with a separate door for the driver, a center aisle with double seats facing forward on either side, an emergency escape door in the rear, a side entrance for the passengers, and a generous luggage rack on top to hold loads of bagged charcoal, crates of chickens, and bundles of firewood. There it was - the real bus. Cooper's sales manager had a sign painted for the display space above the bus windshield and, on his own time and at his own expense, drove the bus from Mombasa to Mraru to show the women what was almost theirs.

The last push became urgent because now that the bus was there to be seen, 


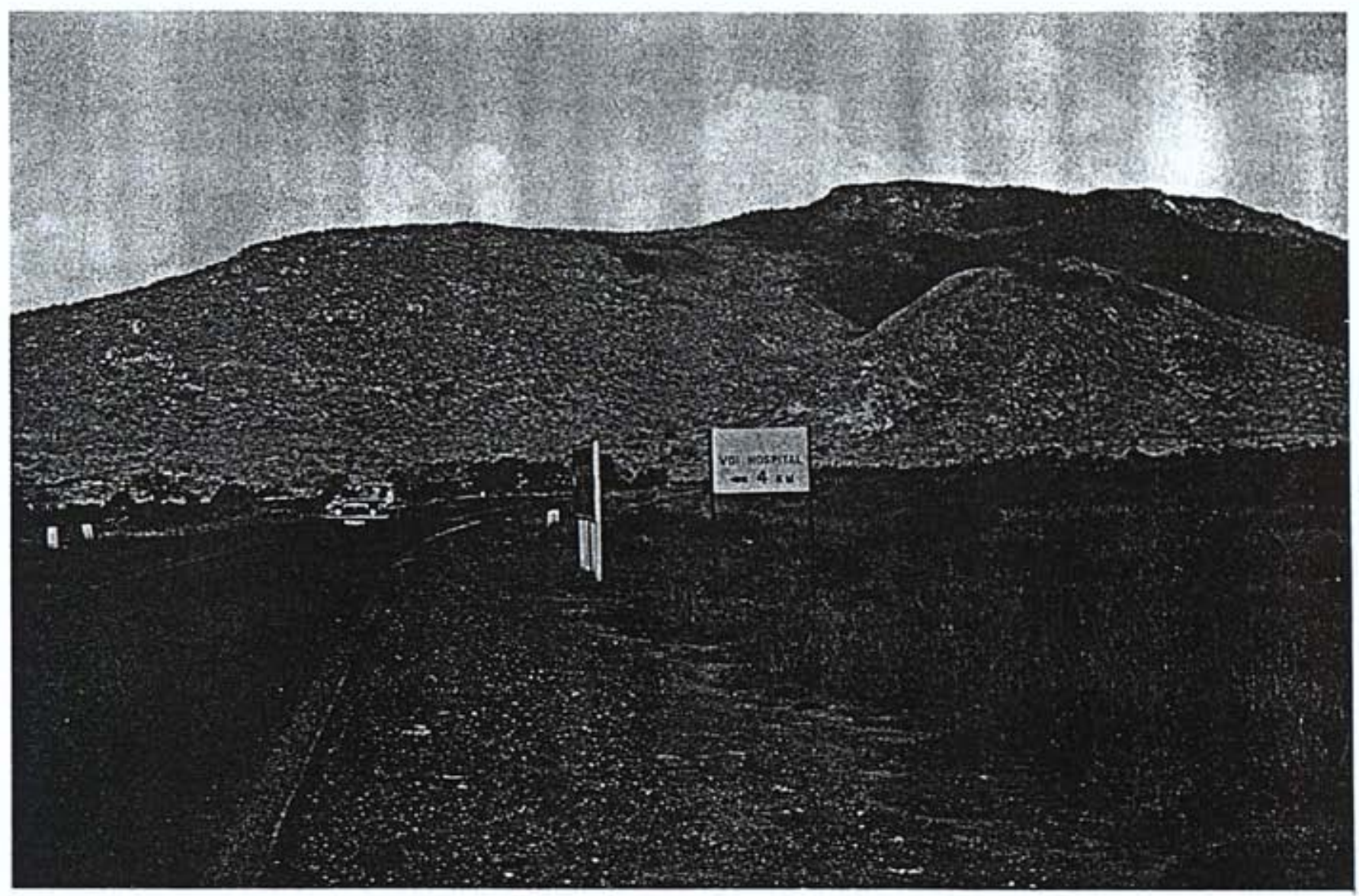

Highway Sign: Voi Hospital, $4 \mathrm{~km}$.

other customers in Mombasa wanted to buy it. But, the Mraru Women's Group treasury was 6,800 shillings short of the required down payment. In their first three years they had raised 27,000 shillings; in the fourth year they raised 14,000 more. But they needed a total of 47,800 .

\section{Last-Minute Rescue}

It is never easy to discover what makes for success, but whatever the magic was, the Mraru Women's Group had it. In the previous ten years, women's groups of various kinds had been forming all over Kenya, but most of them were smaller and had a more traditional focus such as handicrafts, savings, farming or raising livestock. In 1975 , women's groups received more attention than usual because of International Women's Year. Over 70 percent of adults in rural areas of Kenya are women, often left behind to keep the home and raise the children while their husbands migrate to the cities for wage-paying jobs. In trying to plan ahead for rural development, Kenya had begun to take account of what women were doing and were capable of doing. The Mraru Women's Group was surely a fine example and one becomimg well-known in the Coastal Province.

At that time, the chairman of Maendeleo ya Wanawake for the district of Taita/Taveta was Mrs. Joan Mjomba, who herself had grown up in one of the villages of Mraru. Although she no longer lived in Mraru, she joined the group to show her enthusiasm and support. In early 1975, at the Government-sponsored provincial seminar for the International Women's Year, she described the Mraru women in glowing terms and urged the provincial office of social services in Mombasa to make a special example of it in its reports for the Women's Year.

The sense of excitement about what the Mraru Group had achieved so far was not surprising. After all, the group had started with no assets, no special talents, and no wealthy members, yet it had saved an incredible 41,000 shillings in just three years. Now it was on its way to persuading a bus company and a bank to break tradition by lending money to a group of women.

A crucial factor in finally securing the bus was one of the Government's provincial social workers in Mombasa, Terry Kantai. She personally guaranteed a loan for the final 7,000 shillings needed for the 


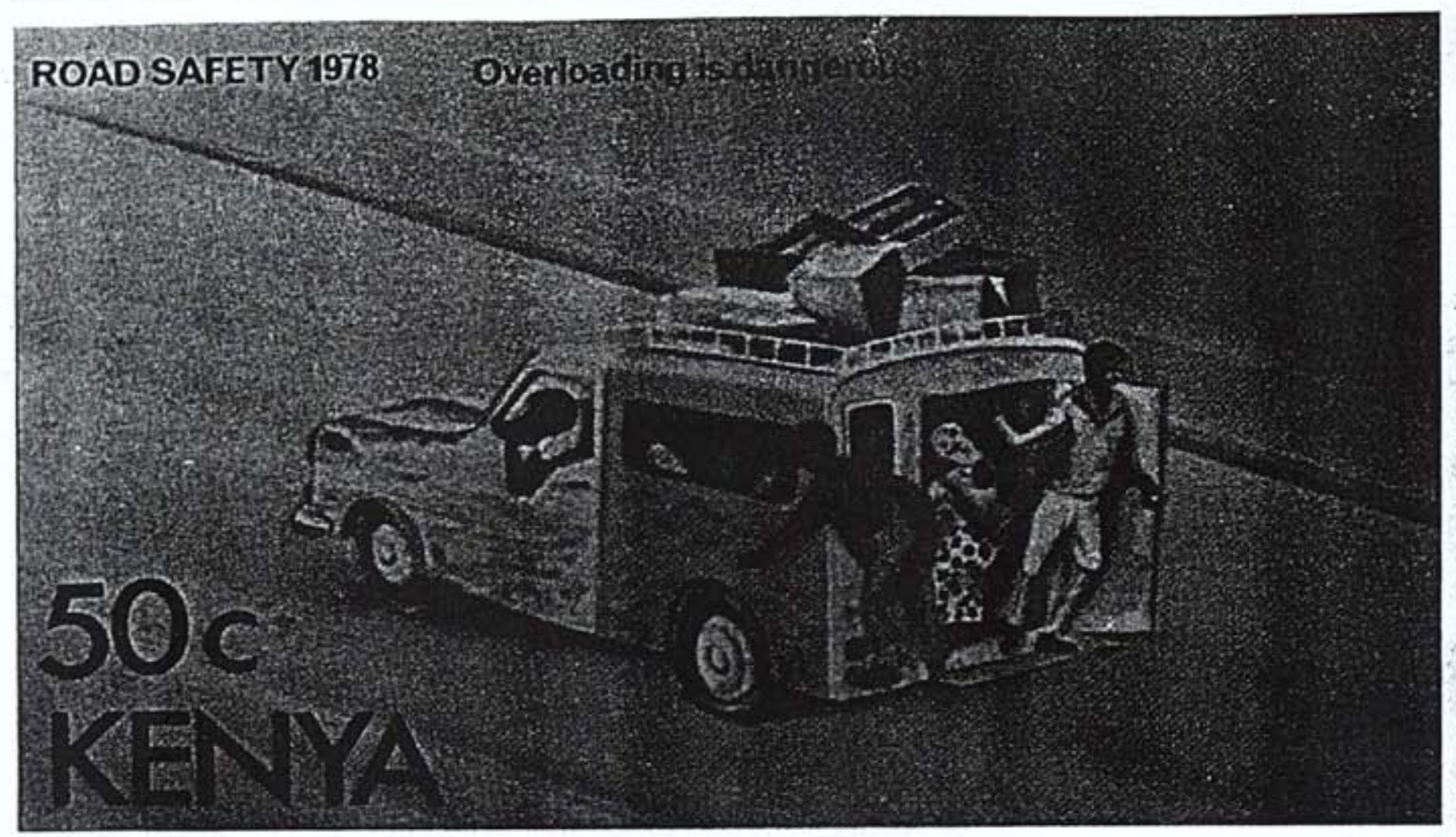

Matatu: The poor man's taxi service.

down payment. Then she, the Maendeleo organization and the Mraru Women's Group organized a harambee fund-raising to show the bank and Cooper Motor Corporation that they could rely on this group to pay off its debts. At the end of the ceremonies the group had collected 3,013 more shillings from 484 donors - enough for the first two payments on Terry Kantai's loan. With the complete down payment now available and the skeptics convinced, the bus could at last be released from the warehouse. Jubilant, the group hired a driver, and on May 3, 1975, the Chairman, Eva Mwaluma, and the treasurer, Mary Frederick, went to Mombasa, claimed the bus, and drove it back to Mraru. Next day, the shining white bus began plying the route between Mraru and Voi.

The Mraru women now had a full-scale business on their hands. They had insurance and registration fees to pay, they had to buy petrol and pay for maintenance, and they had to meet a monthly debtretirement payment of $4,088.90$ shillings over a period of 18 months. In addition, they had three full-time employees: the driver; the conductor, who collects fares and issues receipts; and an inspector. At first the Mraru women hired a woman conductor, but the customers sometimes proved too rowdy for her to handle so a young man was employed for the job. The inspector, however, is always a member of the group who rides on every trip to be sure fares are collected and accounted for. This is a demanding job and she gets paid for it. At the end of each day the receipts are taken to the group's treasurer in Mraru who verifies the total and enters it in the books. The next morning the inspector deposits the money in the bank at Voi.

Each passenger pays 3 shillings for the one-way, 12 kilometer trip from Mraru to Voi. The bus leaves the main intersection in Mraru (the junction of two dirt roads) at 8:00 a.m. every morning and continues back and forth to and from Voi, with four or five stops in between, as long as there are passengers who want to make the trip. In-a refreshing switch on the original situation, members of the group get first preference when there are too many passengers for one load.

A day's gross for the bus service can vary from 120 to 800 shillings; on market days and holidays it can reach several thousand. The bus is also available to hire for special trips. A typical one was made for the Taita/Taveta Education Board, transporting school choirs from one town to another; the charge, 400 shillings round trip. If a job requires an overnight stop, the driver, conductor, and inspector are paid a small allowance for overnight expenses. 


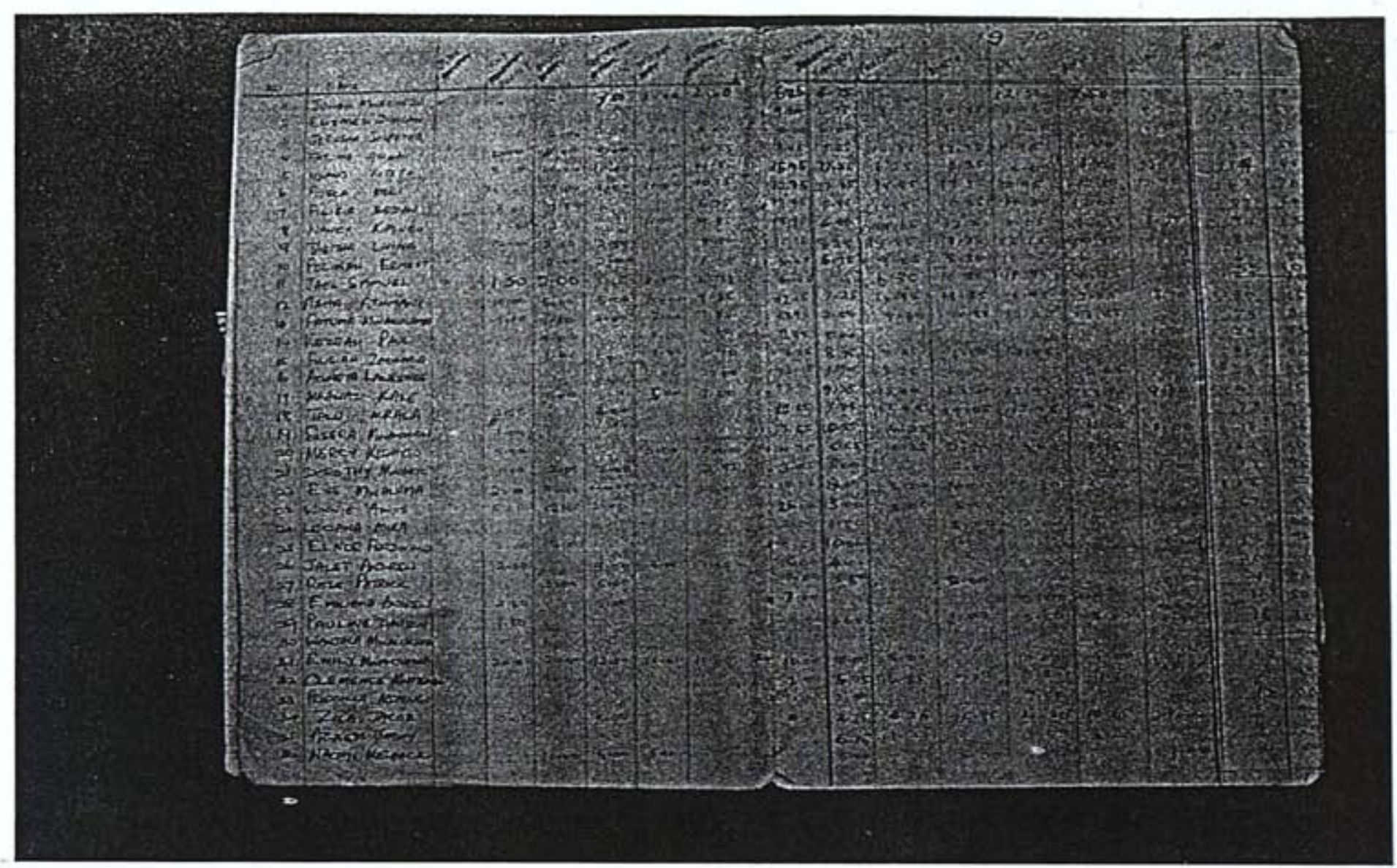

Donations noted in the record-book.

\section{Diversification}

The bus proved an excellent investment. Demand for its services was so lively that the driver worked seven days a week and was given vacation pay instead of time off. In a year and a half, the debts were paid and the Mraru Women's Group began a new savings account. By 1977, they had 12,000 shillings in the bank and were accumulating more all the time. The group then declared half the money as a dividend and targeted the remaining funds for a new enterprise, a duka or retail shop in Mraru. The dividend, distributed in proportion to each woman's shares, was a stunning success. Women who had never owned anything in their lives, and many who had pursued this project despite their husbands' disgruntled complaints, now were receiving a return on their investment. News like that spreads quickly. The group had 68 members at the time of the dividend; within two years the number had grown to 195. Many of the new members were women with more ready cash than the first group; quite a few of them could afford 200 shillings outright.

\section{The Duka}

Almost as soon as they were able, the women decided to invest in another enterprise. The bus, though a good earner, seemed too vulnerable. They again chose a business serving the local market; however this time it was not movable, but a solid asset. The women applied to the Taita/Taveta County Council for one of the plots in Mraru that the Council had specifically set aside for such use. Again drawing on outside expertise for estimates of costs and needs, the Mraru women decided to start small, with only a shop. At a future date they would hope to expand the building to include quarters for employees of the bus service and the shop, an office, a meeting room that could double as a classroom, a kitchen, an indoor toilet, and five bedrooms that would-serve as a small hotel.

The shop and three small rooms made of cement block with corrugated roofing would cost 55,000 shillings; stocking the shop would cost another 22,000. The funds came from new members who had been joining under the impetus of the dividend and the group's savings of 6,000 shillings in profits from the bus - an amount which was growing every week. With plans approved by the Council, construction of the duka began in February 1977 and was completed six months later. The Govern- 


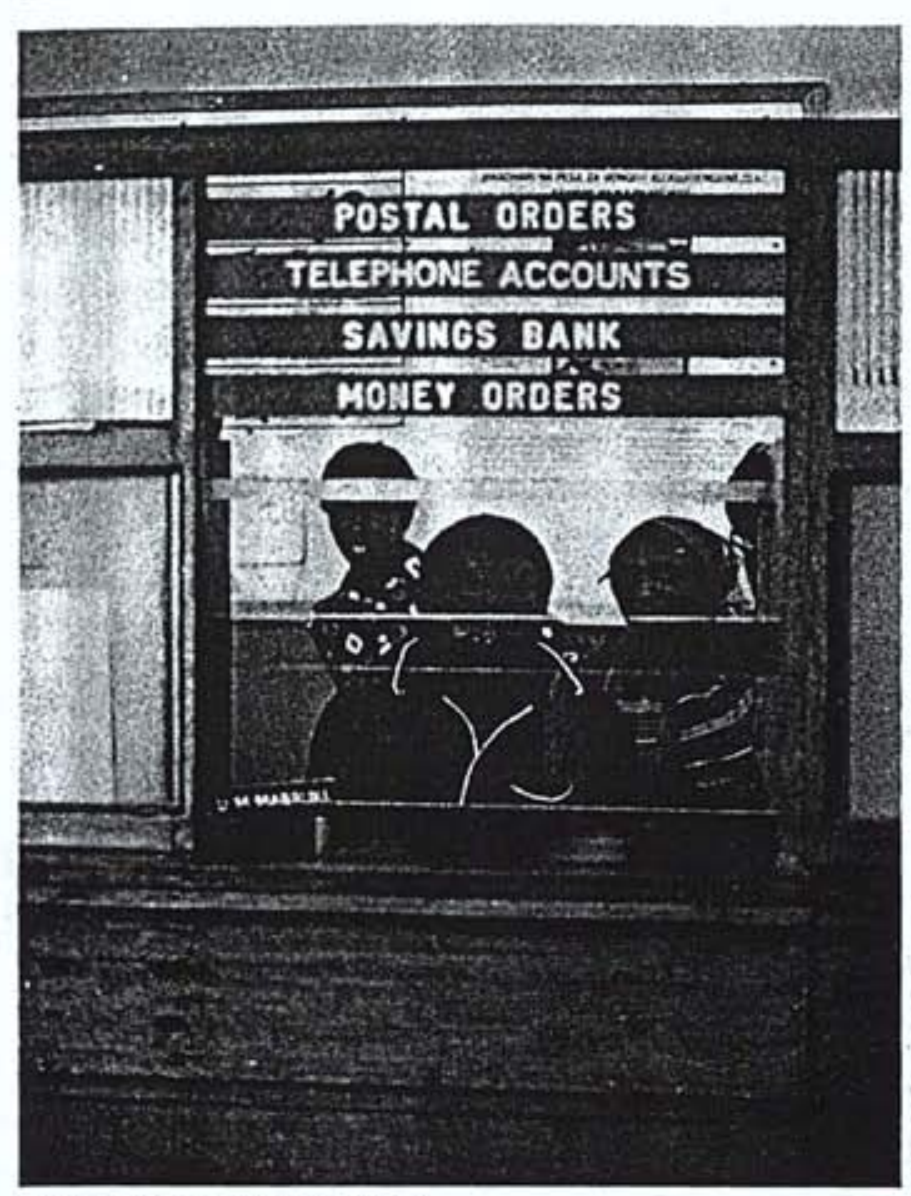

P.O. savings window at Voi.

ment Social Services Department made a loan of 10,000 shillings to the group to help stock the duka, even though their advisers were concerned that the shop might be being built a few years too soon in the general scheme of things.

Elina Mwaizinga, a member of the group, is now the full-time salaried shopkeeper. Rising early from her bedroom behind the shop, she opens the doors at 6:00 a.m. and does not close them until 7:00 in the evening. This is her daily schedule except for Sundays when she closes the shop for a few hours at midday to go to church, and on the days she goes in to Voi to buy supplies from the wholesaler. The duka stocks simple household items: aluminum cooking pots, skin-toning cream, malaria tablets, canned cooking fat, nipples for baby bottles, pyrethrum insect spray. Its biggest sellers are sugar and tea. Wholesale costs, of course, are one of the major expenses of the shop. So is Elina's salary: 300 shillings a month. While the shop's location is not ideal for a retail business, since the population that can reach it easily is small, it does have 195 unswerving customers who will not buy their goods anywhere else. Members pay the same prices as other buyers, which are more or less equivalent to the standard retail prices in other shops. Although all of them patronize the duka faithfully, their business isn't taken for granted. At the annual year-end meeting and party, members are invited to show shop receipts for purchases of more than 50 shillings, which entitles them to an item off the shelves. "That's to please the customers for coming," says Elina.

Although the shop is not nearly as profitable as the bus, it represents a solid asset. "The thing we are proud of is that investment," says one of the members. "We will never be counted bankrupt with that there." The cement-block building could always be rented in hard times. It could even be sold, but the group is determined never to have to do that.

\section{Further Development}

As a registered women's group, the Mraru Group is eligible for continuing assistance from the Governemnt, including advice on further investment to protect against any problems in its other businesses. On the advice of Government social workers, the group has begun raising goats and studying for self-improvement. These more traditional pursuits of women are both substantially underwritten by Government funds.

The Taita Hills area is extremely dry at times, which makes goat raising a better investment than farming. Besides almost every woman in Mraru is skilled in raising goats. The Women's Bureau in Nairobi, with funds from UNICEF, provided the Mraru Women's Group with 100 goats, plus two outstanding he-goats to help them develop their stock. The male offspring are sold for meat at about one year of age, the females are kept for breeding.

Group members added 30 more goats to the herd, and the village of Mraru also contributed by granting the women's group free use of grazing land on one of the hillsides about half a mile from their shop. A goatherd, whose salary is 240 shillings a month, is the enterprise's largest operating expense.

The major capital expense was a building to house goats and herdsman: 350 shillings for poles on which to plaster clay walls, 700 shillings for corrugated roofing sheets, and 150 shillings for the builder. The builder and poles were paid for by members' donations, but the money for the roof came 


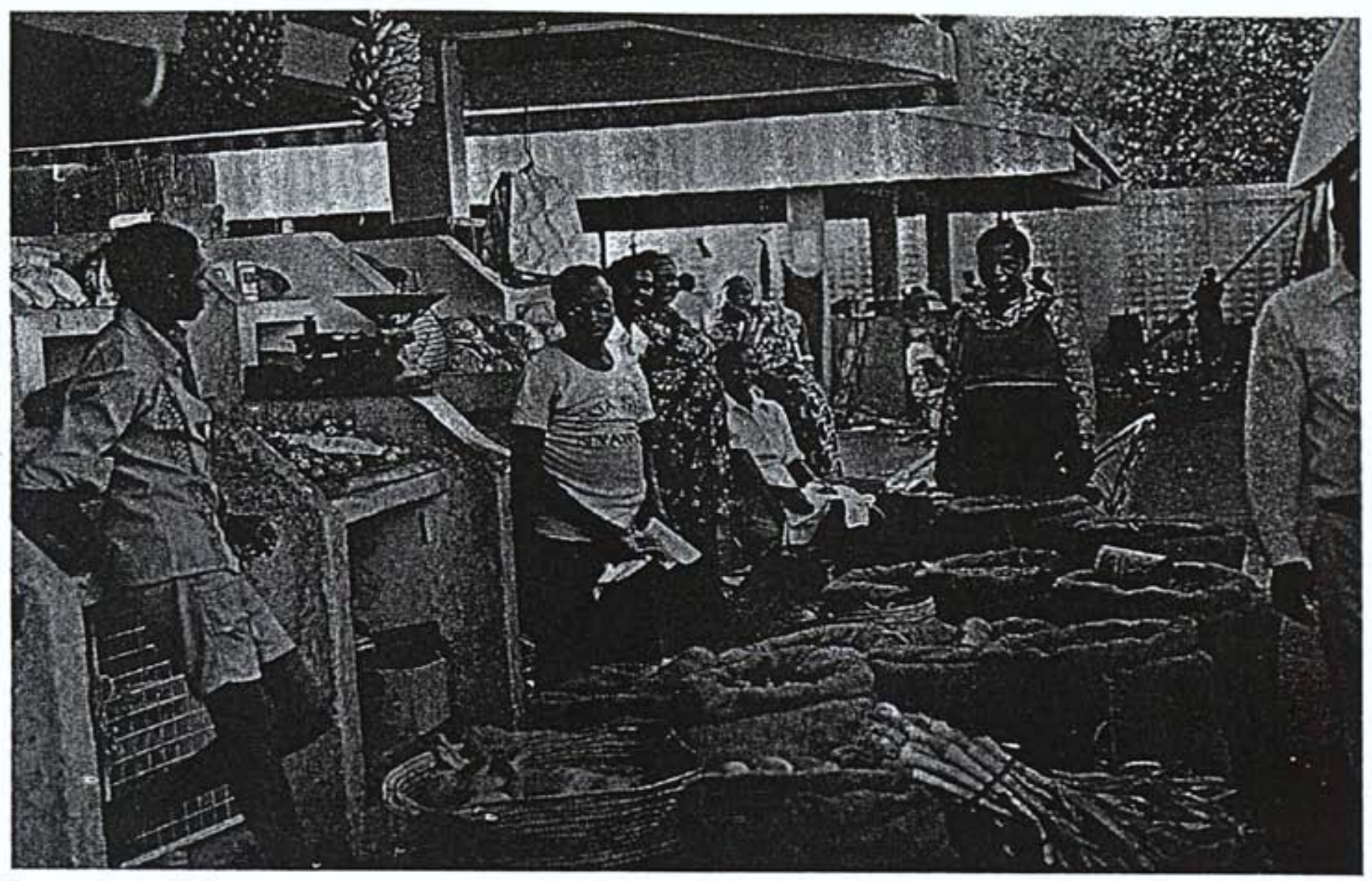

The market at Voi.

from the profits of the duka. As it turned out, the shop was not quite profitable enough to cover the whole cost, so the side toward the hill is roofed with empty tin cans cut open and hammered flat, contributed from members' households.

Unfortunatley, goats are a more vulnerable investment than canned cooking fat, and the first year of this undertaking was a year of drought. Some of the animals died, including one of the prize he-goats. In order to protect their stock, the Mraru women sold a number of the remaining animals so they would have the cash to expand the herd when the rains returned and grazing was good. As of May 1979, the herd stood at 48 goats and the rains were blessing the hillsides.

The group began one other new enterprise at about the same time, this one aimed more at personal improvement than profits for the treasury. Here again, it received substantial Government assistance. The Social Services Department donated two sewing machines and the salary for a teacher to live in Mraru and give classes in sewing and family health. The Department also gave the group 3,000 shillings for sewing materials. A monthly fee of 10 shillings per participant pays for small supplies like needles, thread, and buttons. The teacher, Dora Malemba, works full time and lives in a room behind the duka. She holds classes for one group of women in the morning and another in the afternoon. Her 28 students, who almost never miss class except in the planting season, spend a good part of the sessions working on the two sewing machines. Although this project was intended for personal improvement, many of the dresses, jackets, tablecloths, and children's clothes the women produce are sold next door in the shop. In the first eight months of classes, the group made almost 1,000 shillings on the sale of these items.

In addition to sewing, Dora teaches the women about health and family planning. She works every day from a lesson plan she has devised in advance. Classes are informal with women wandering back and forth from the duka and babies tied to their mothers' backs or playing on the floor.

\section{Organization}

The group still meets once a month at which time money is collected and the number of shares increased. Women who do not attend meetings are fined. (This is a 


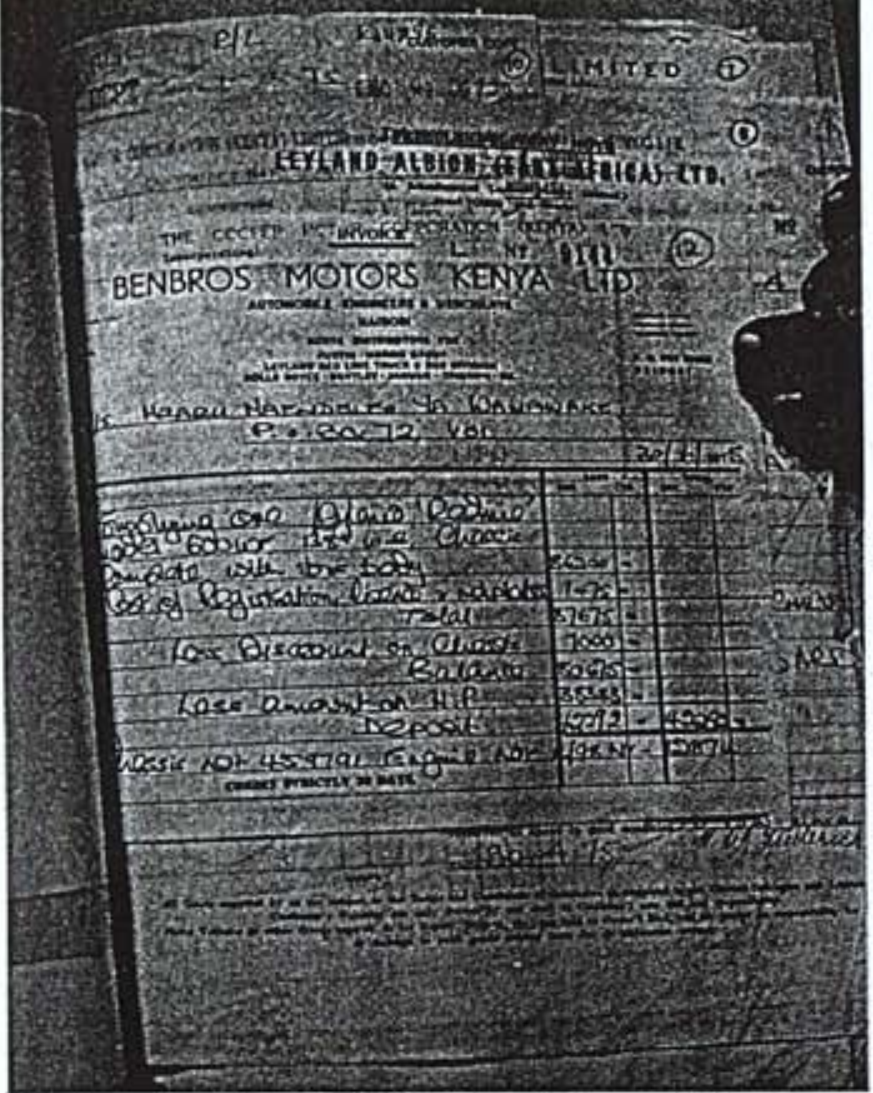

Final purchase form for the bus from Cooper Motor Corp.

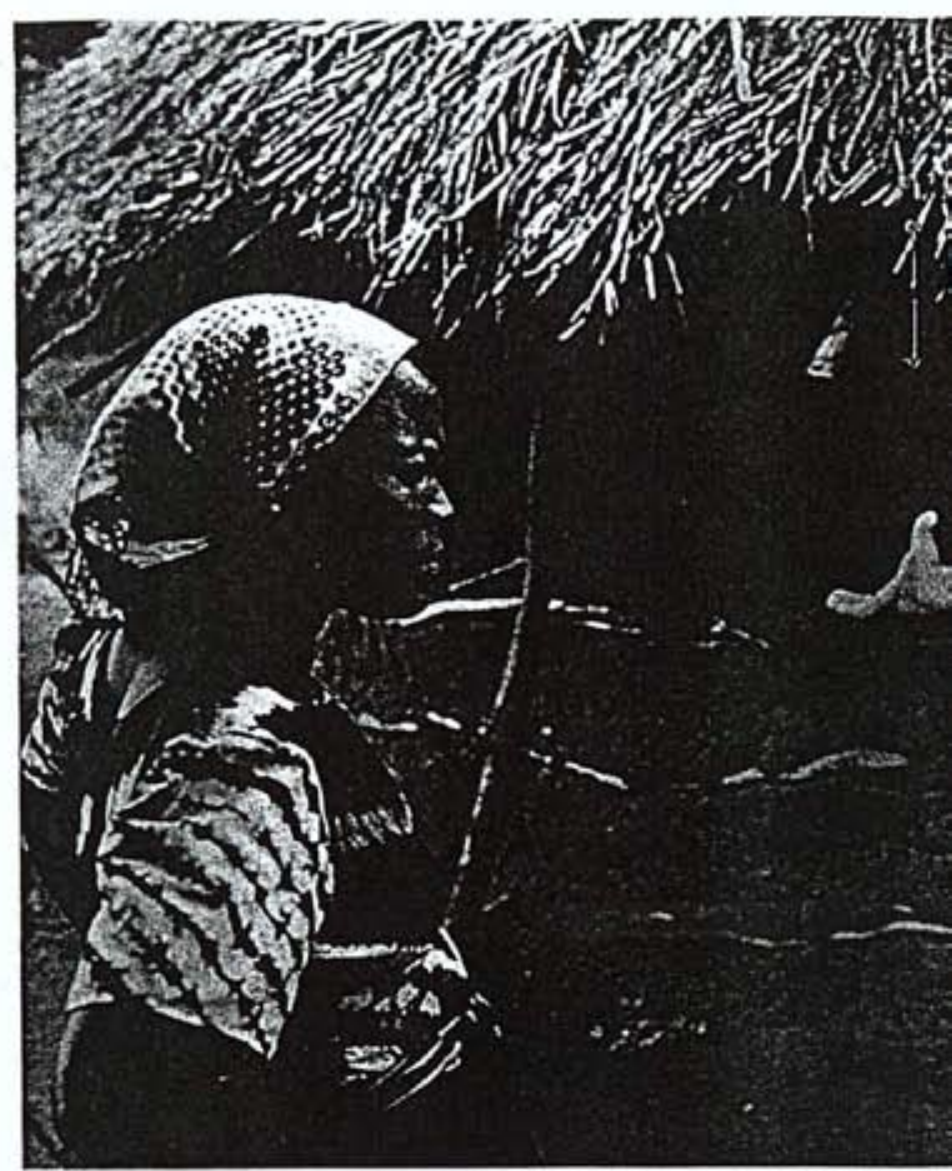

Joan Mjomba, right, talking with the vice chairman of Mraru gro

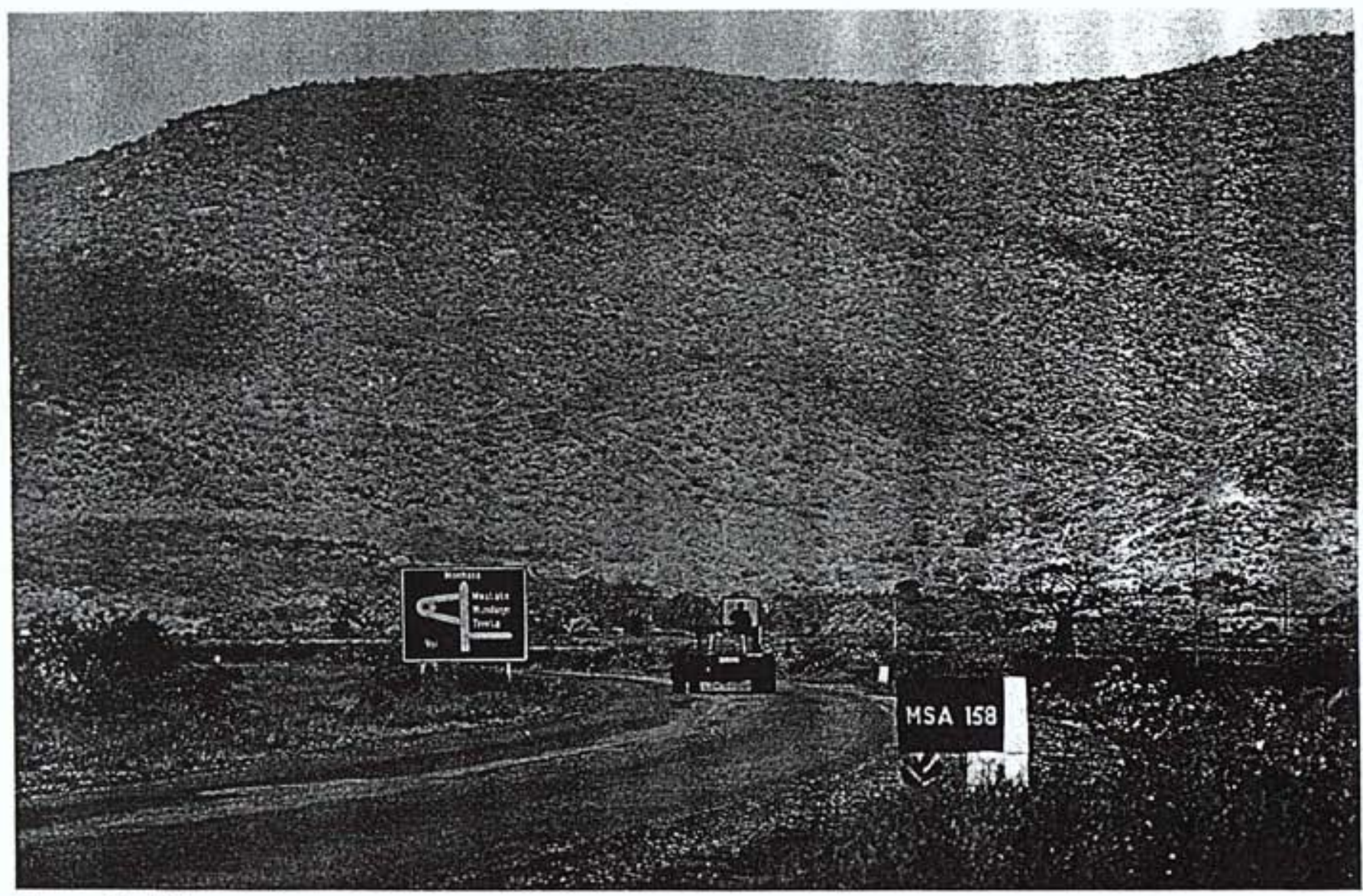




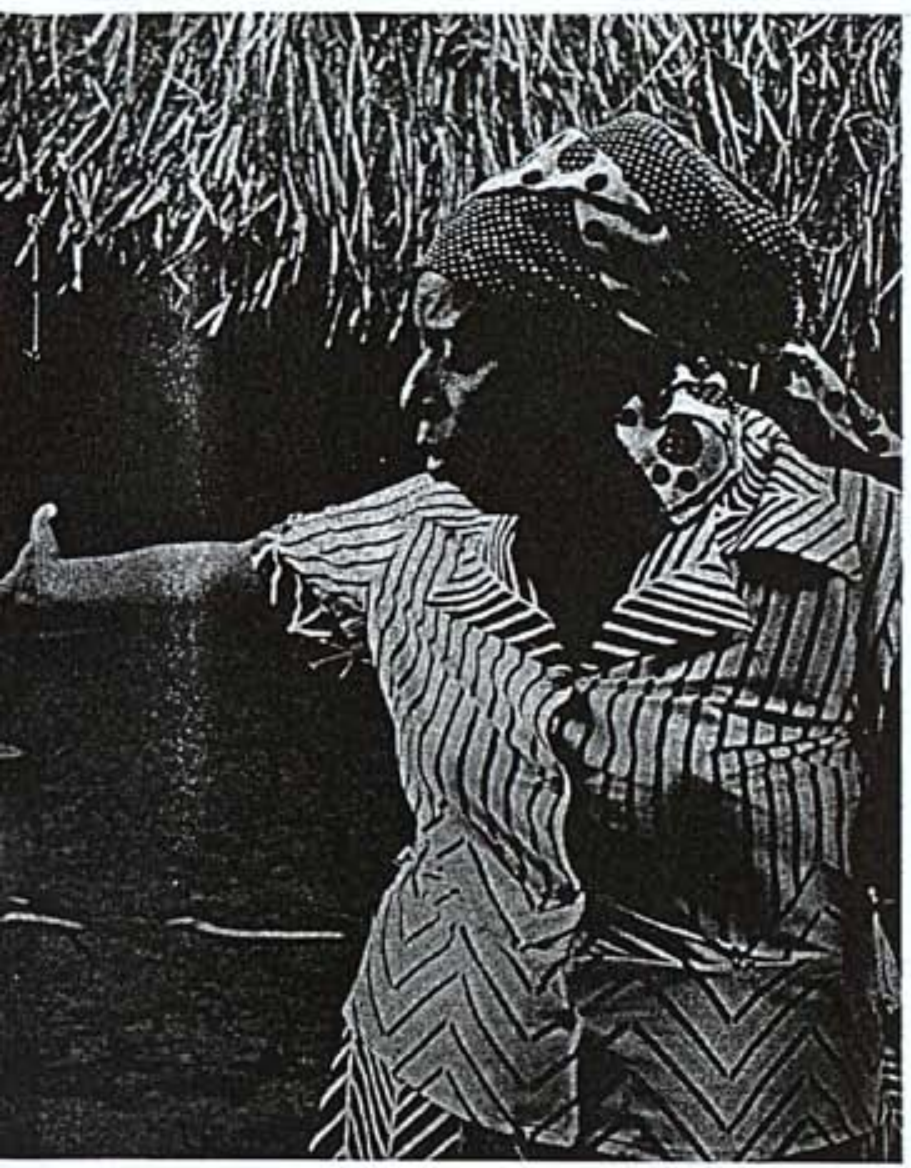

group, Polina Danson.

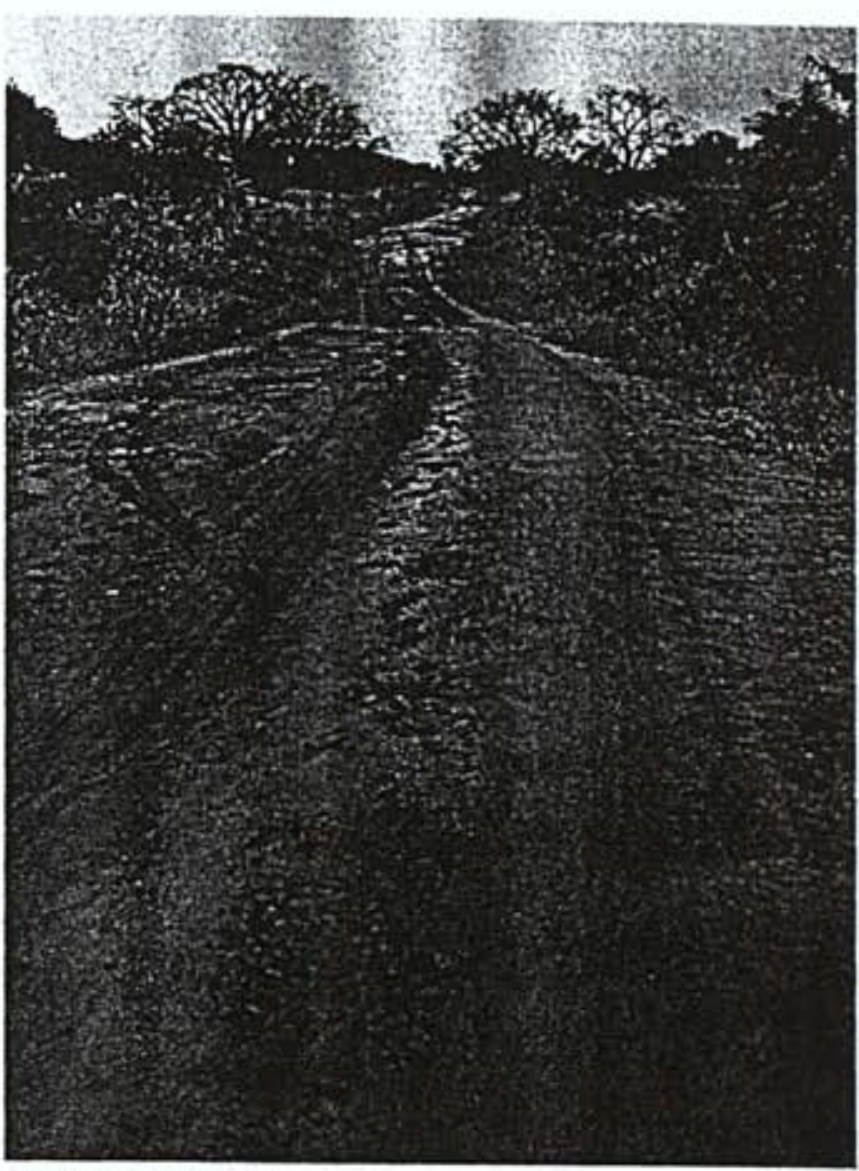

The road to Mraru.

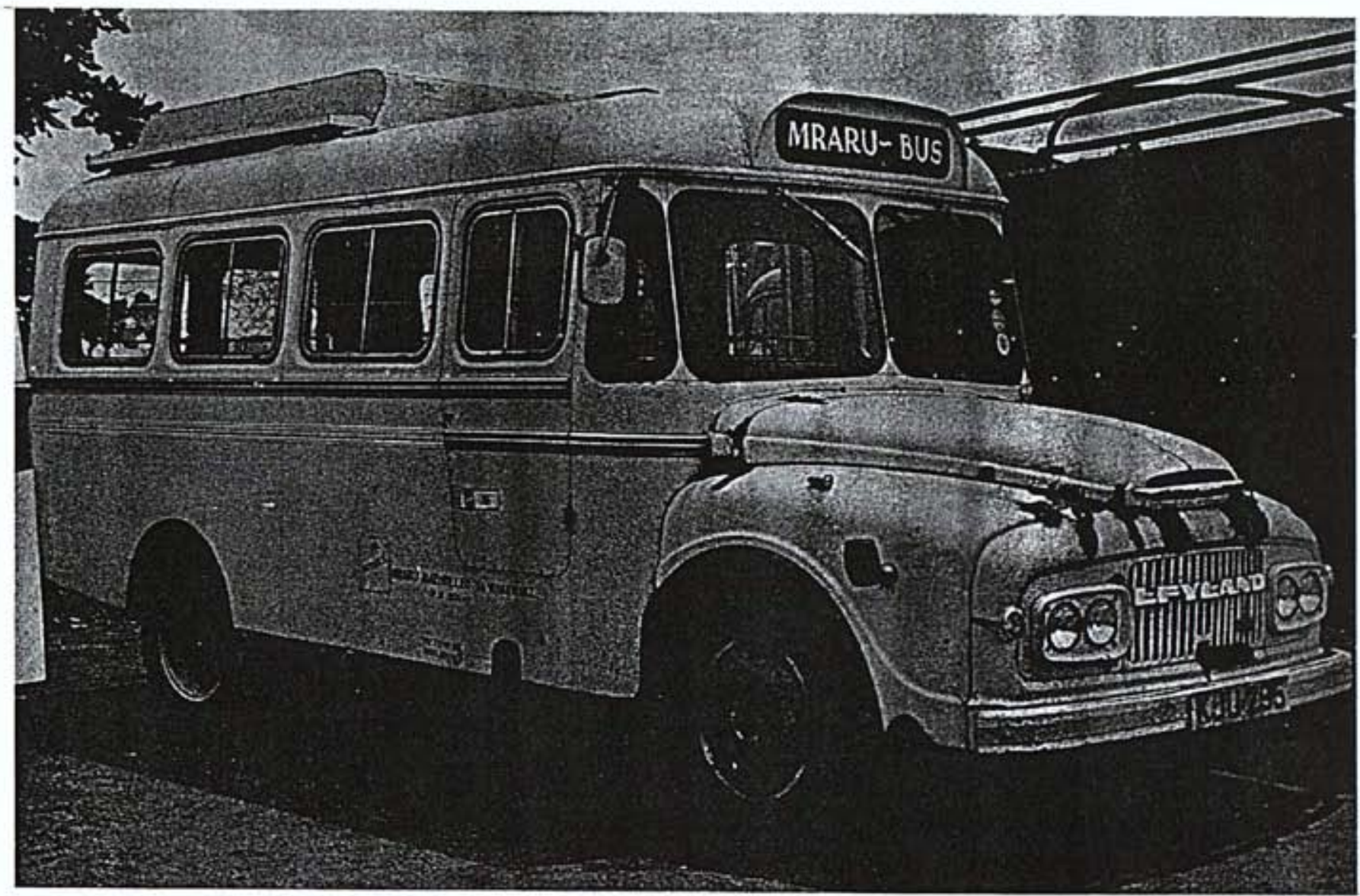

The original bus at retirement in 1979 


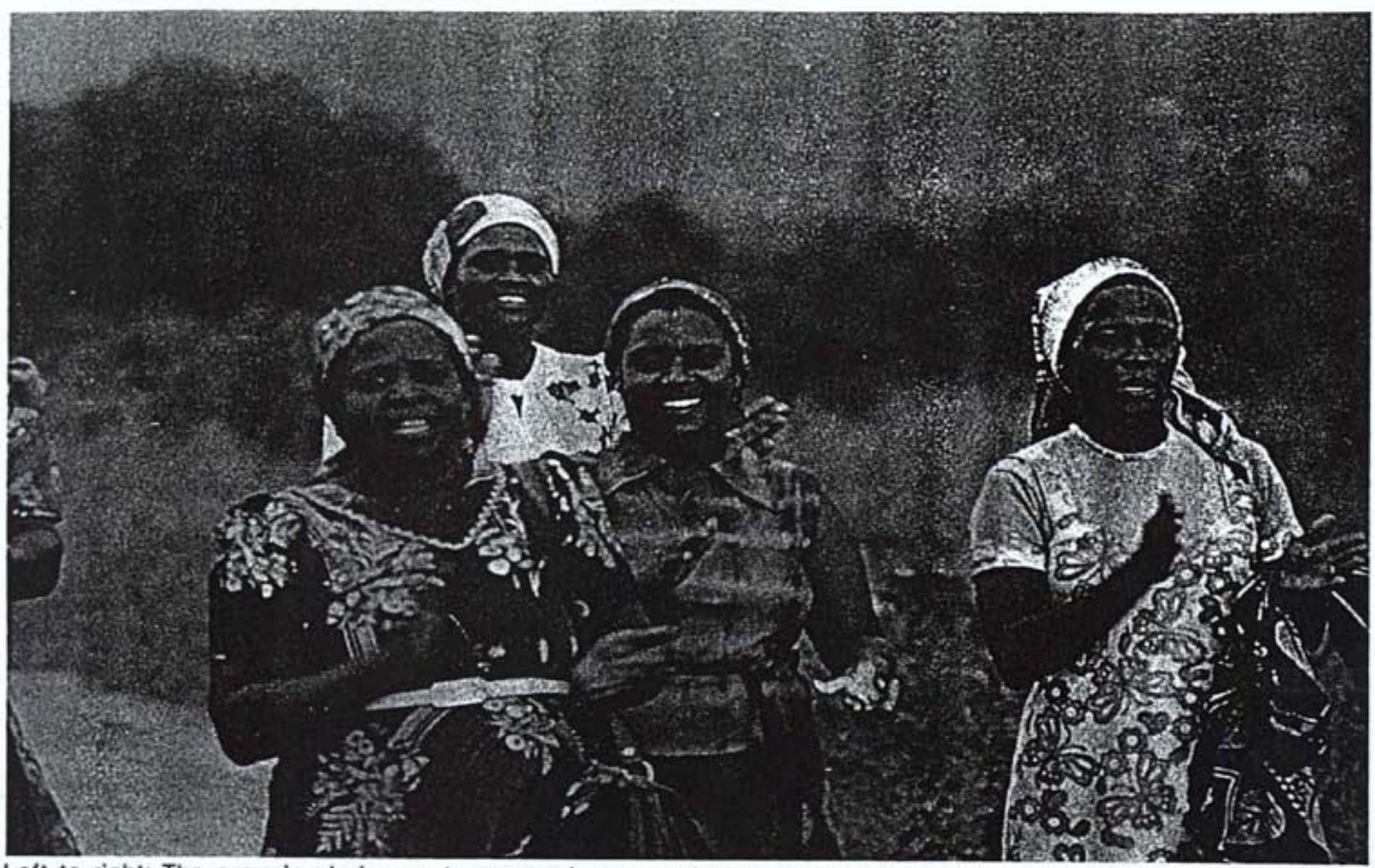

Left to right: The group's chairman, treasurer, instructor in home economics, and vice chairman. On any special occasion and at every meeting, the group sings the song. "Maendeleo ya Wanawake."

general tradition in Kenya, to keep up attendance at all kinds of meetings.) One share in the group is still worth 200 shillings, and the women have set eight shares as the maximum any individual may buy. "We don't want to have some women who are better than others," the chairman has said. In fact, the aim is to bring every woman's holdings up to eight shares so all will be equal, but that probably will have to wait until the group again has enough income to declare a dividend.

For business purposes, full-scale meetings are clearly too cumbersome, so the group has elected a committee of nine members to consider policy, look into problems, and make recommendations to the full membership. The majority rules, and election is done by secret ballot. The committee, which meets once every three months, unless a pressing matter requires an extra meeting, is also responsible for choosing the group's officers - chairman, vice chairman, secretary, vice secretary, and treasurer. These women in turn have their own special duties. The work of the treasurer and secretary are demanding enough to warrant their being paid a monthly fee of 100 shillings each. The secretary records the amount of money deposited monthly by each member and keeps a cumulative tally so it is clear where members stand in their ownership of shares. The treasurer has the daily job of counting the bus receipts and entering the total in the books.

None of the officers has had special training for her job. The treasurer, for example, has a secondary-school education but no background in accounting. Once the books were set up by a professional accountant, she has had no trouble maintaining an accurate record of the group's financial transactions. The professional accountant, from the County Council office, is hired by the group to go over its books once a year. This underscores one of the secrets of the Mraru Group's success. From the start, it has sought and received professional assistance. Government social service workers have counseled the Mraru women on how to organize, on investments, and on the details of running a business. The group has had the invaluable counsel of Terry Kantai, first as an employee of the Government's Social Services Department in the Coast Province and now as director of the Women's Bureau in the national government. They also have received advice from members of 


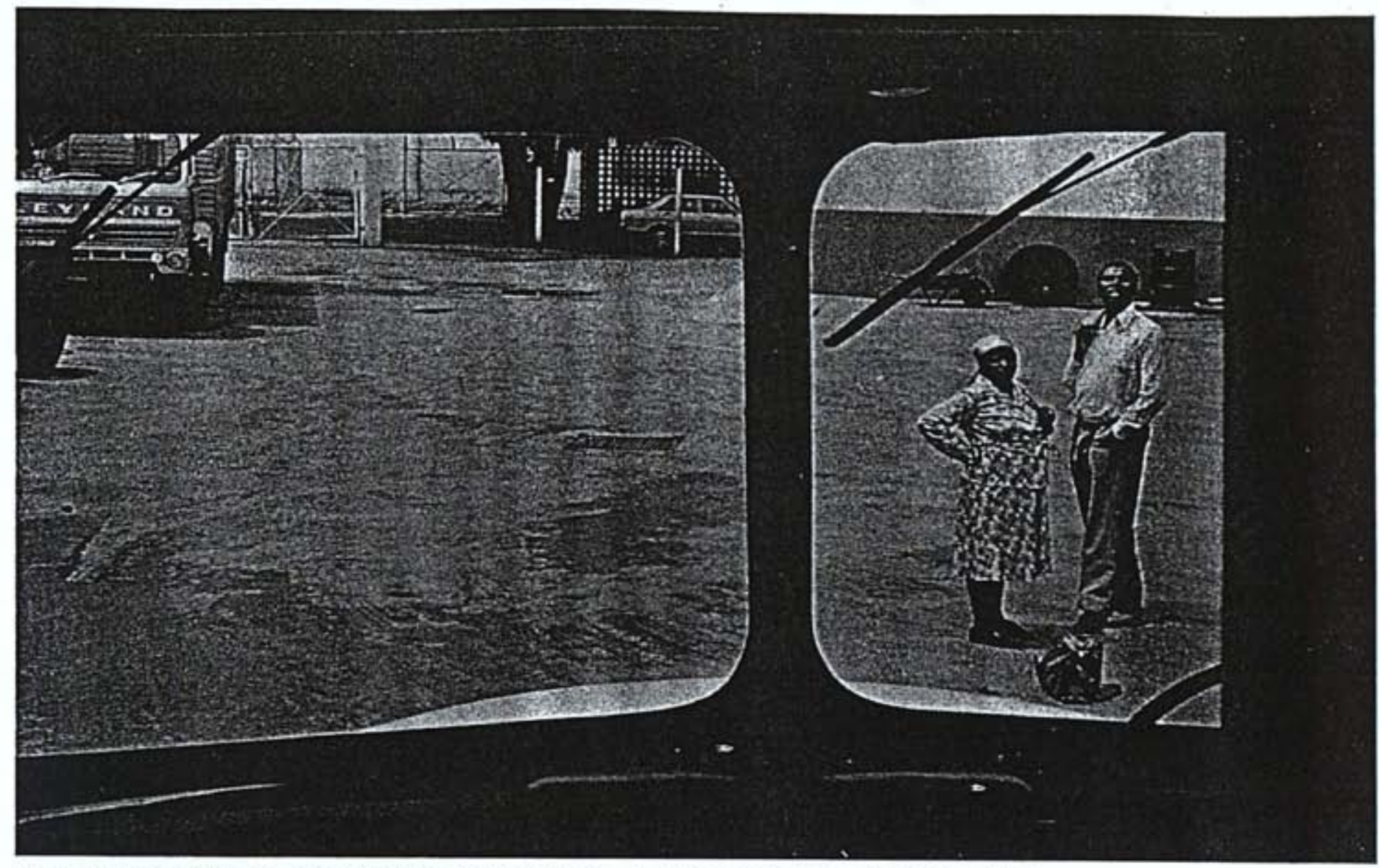

Mr. and Mrs. Mwaluma, standing together on tarmac, seen through the windshield of the bus.

all levels of the Kenyan Ministry of Housing and Social Services, the Community Development Assistant of the Department of Social Services, the District Social Services office, and the County Council.

The Maendeleo ya Wanawake national organization is also available for counsel and instruction. Maendeleo can lobby with various government divisions on behalf of any one of its member groups and command far more attention than a single group, even one as substantial as the Mraru Group. The extraordinary energy and enthusiasm of Joan Mjomba, first as district and then as provincial chairman for Maendeleo, was likewise an advantage other groups might well envy. None of these advisors, national or local, intrude on the Mraru women, who clearly would be able to resist interference if they needed to. But obviously the women do not operate in a vacuum. If they want further counsel on any matter they can usually get it.

\section{Crisis}

Despite its growing diversity the group has had only one substantial moneymaker, the bus. But years of steady use on rough roads have worn it out. By the time the bus reached age $41 / 2$, repair bills began to equal earnings and the group decided it was time to turn the machine in for a new one. At this point, the Mraru women met their first major setback.

In the years since their first puchase from Cooper, inflation had been rampant worldwide. Added to that, Kenya had a foreign exchange crisis that forced the Government to place high tariffs on goods from abroad. The bus the women now wanted to order was slightly larger than their old one, seating 26 rather than 21 . Cooper was willing to give them good tradein value for their old bus - 60,000 shillings and beyond that, they had 31,600 in savings. This would almost have bought their old bus outright in 1975, but in 1979 the Cooper managers shook their heads. Now a new bus, with insurance, registration fees, and interest on a loan included, would cost about 310,000 shillings. Although the group had a flawless record for repayment of loans, money was much tighter now and the best loan Cooper could arrange was for a maximum of two years. That would mean monthly loan retirement payments of nine or ten thousand shillings. The Cooper manager and Mrs. Mwaluma agreed that the 


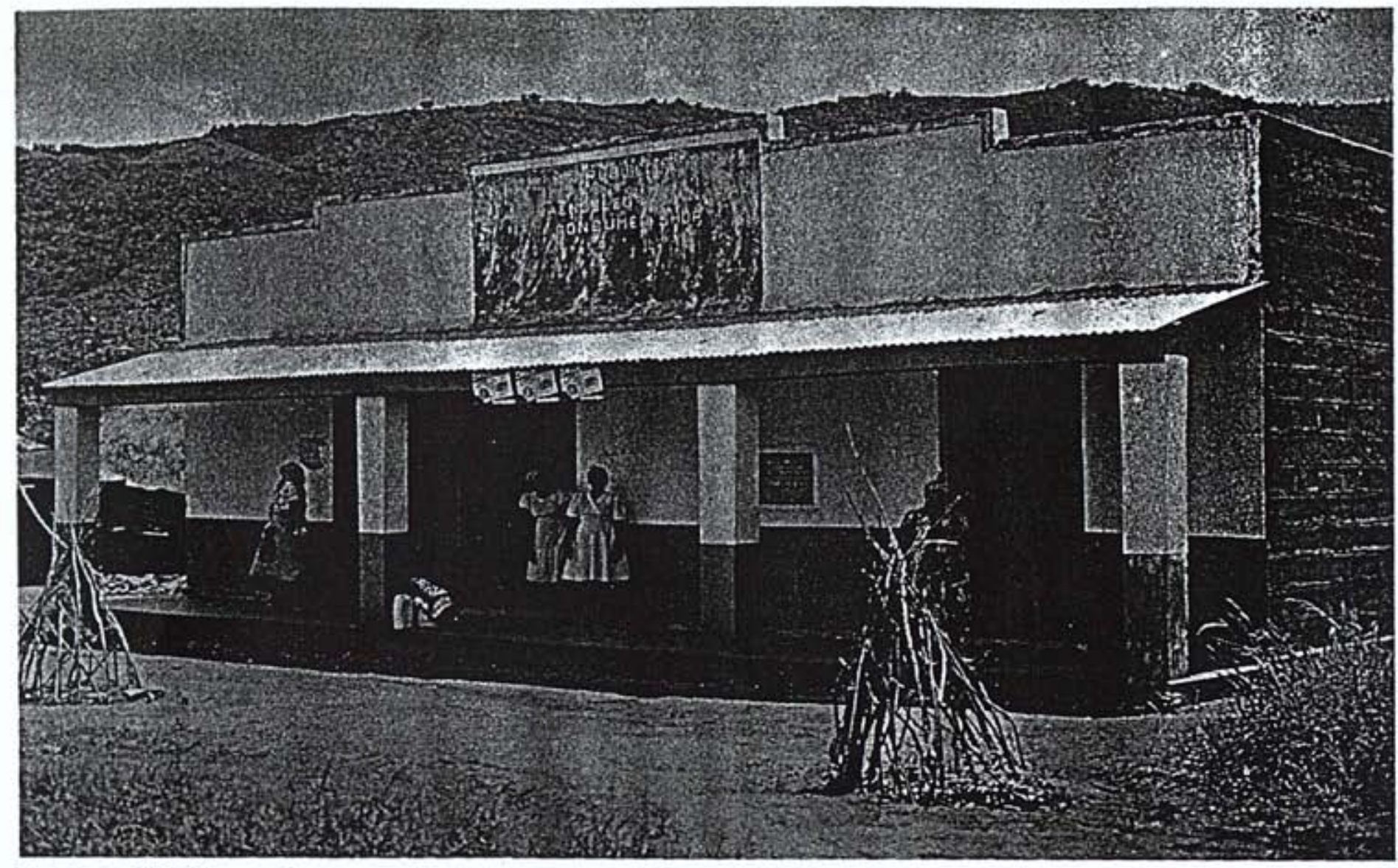

The shop. "We'll never be counted bankrupt with that there."

income from the operation of a single bus could not sustain such payments.

Some of the group's decisions now had to be evaluated in a new light. They had chosen to invest in the duka rather than save for a new bus. While the Cooper Motor Company was sympathetic, they had to have a minimum cash down payment much larger than the group's savings. The duka should have been sufficient collateral for a long-term loan, but the land and buildings in Mraru have not yet been surveyed and centrally registered with the Ministry of Lands and Settlement in Nairobi. This means that there is no deed to the building and, without a deed, no bank will grant a mortgage.

As of this writing, the group's dilemma remains. The old bus, too tired to continue as is, has been retired and sits in the Cooper yards in Mombasa. Although Cooper has ordered the new bus, it will not release the vehicle without first receiving at least half of the total price in cash-approximately 60,000 shillings more than the group can currently muster. The Mraru Women's Group clearly needs to raise more capital, but its only substantial source of income is the bus service, and that is not running. The women of Mraru are experiencing some of the old problems they had almost forgotten: once again it is difficult to get to Voi. Although they can now make simple purchases nearby at their own shop, individually they have less money to spend because they cannot get to Voi to trade.

However sobering, the setback seems temporary. The group has assets: its old bus, its building, the shop's inventory, the goats, the herdsmen's building, over 30,000 shillings in cash, and goodwill in many places. It seems likely they will find some way of obtaining the loan they need. The strong spirit that has carried them through so much hasn't wavered. They discuss their plans for more goats, the hotel, and with the encouragement of the Cooper sales manager, the hope that after they get the new bus on the road they might reclaim and restore the old bus so they would have the wherewithal to give each vehicle proper servicing while still keeping up a regular schedule. Some of their advisers, anxious that the group not overextend itself in one area, have raised questions about expanding the bus service. It will be the women of Mraru, however, who ultimately make that decision. And whichever choice they make, 


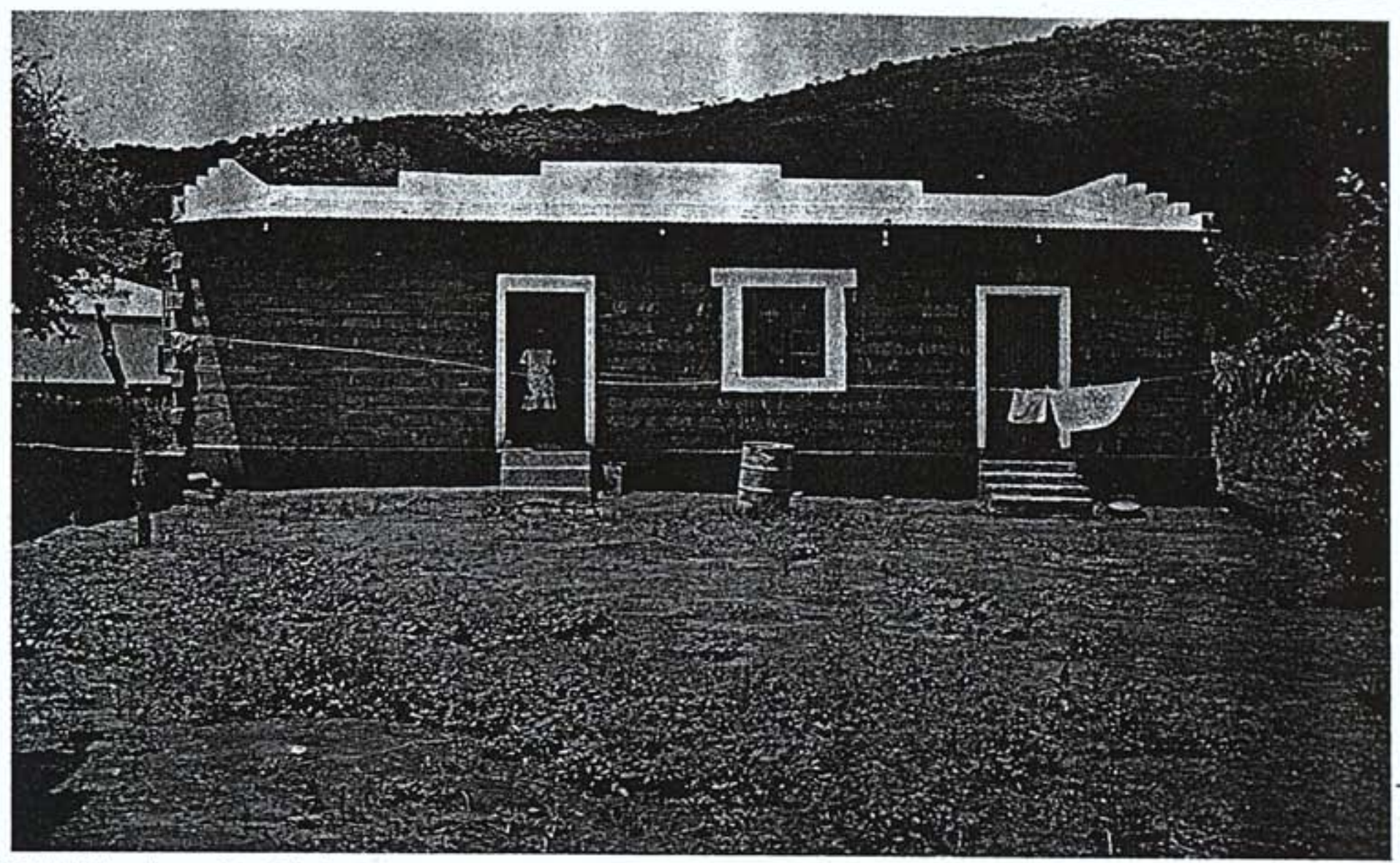

Behind the shop: site of the hotel.

their story augurs well for women and development in Kenya.

\section{Lessons}

The story of the Mraru Women's Group is a story of courage, ingenuity and persistence. Members have learned a great deal about the rewards and the problems of economic enterprises, information useful to women in other countries:

1. It is important to select a product or service for which there is a strong local demand: Both the women and their com. munities needed better transportation services. The demand for a small retail shop was evidently less strong so the immediate returns have been smaller. The duka does, however, have the advantage of being a firm asset, potentially usable as collateral.

2. The choice of product or service should be subjected to the most vigorous possible economic analysis to determine its economic viability: The bank knew the bus could not last long on rural roads and set credit terms accordingly. This seemed troublesome, but in the end served the women well by holding them to realistic economic criteria. The loans provided for the duka and the goats were given on much more lenient terms and perhaps this should not have been.

3. Available support services from individuals and agencies should be used to the fullest possible extent without creating dependency: Small groups often need assistance, especially in the early stages. All countries have resources such as government agencies, national women's organizations, community leaders, and international organizations that can provide advice and assistance. Drawing on their experience can often help solve difficult problems or bring new ideas and energy into a project. But the group also must exercise its own judgment as to what advice to accept or reject. Autonomy is important, too.

4. The design of the project should be kept as simple as possible, especially in the early stages: It is generally best to start small, with one or two products or services and a clearly defined mar- 


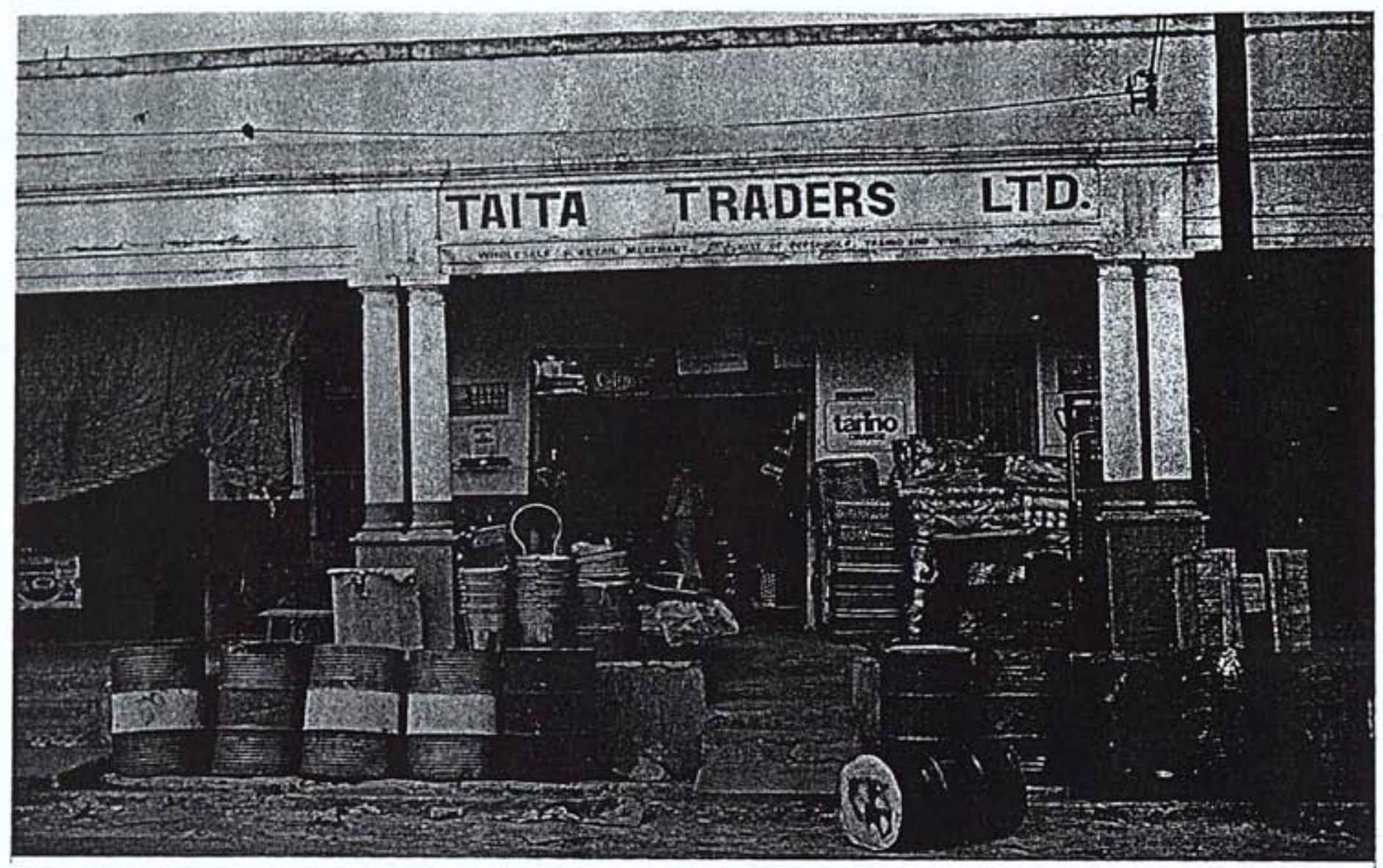

'The shop's wholesaler at Voi.

ket. Decisions on diversification and expansion should be made with the same care as the original choice. Similarly, the project should require only a small staff, easily supervised by the group, at least at the outset.

5. Any group undertaking an incomegenerating project must organize carefully and provide a paid staff to carry out basic operations: In Kenya, women's organizations have a strong tradition of doing this, and can rely on both the Government and the national women's organization for guidance in selecting officers, developing guidelines for savings and investment activities, recruiting and supervising project staff, etc. It is crucial that the procedures and principles agreed upon be followed consistently so that all members benefit and contribute fairly. Officers who have specific responsibilities should be chosen on merit and replaced if they do not perform properly.

6. Most countries and cultures have longstanding traditions on which women's organizations and projects can build: In Kenya the long tradition of harambee, working together, is surely an important source of strength for the Mraru women, not only in building their economic strength but in developing a broader competence to sustain their families and their communities.

The story is not over-the ingenuity and commitment of the women of the Taita Hills is stronger now than ever. They are confident they can find solutions to the problems they face in improving the quality of their families' lives. They know how to accomplish things by joining together. It should only be a matter of time before a new bus pulls out of Mraru on its way through the Taita Hills to Voi. 
The Song of Maendeleo ya Wanawake

Maendeleo ya wanawake Ni lengo letu la daima Maendeleo ya wanawake Ha yana budi kutunzwa

Waume wetu sikilizeni Kwa utulivu na makini Maendeleo ya wanawake Ha yana budi kutunzwa.

Afya nzuri na hali nzuri Ya watu wote wa nyumbani Ya tegemea ya tegemea Maendeleo ya wanawake.
Women's progress Is forever our aim. Women's progress Must be our pursuit.

Our husbands, listen Tentatively and carefully. Women's progress Must be our pursuit.

Good health and well-being For everyone in the family It depends-it depends! On wamen's progress.

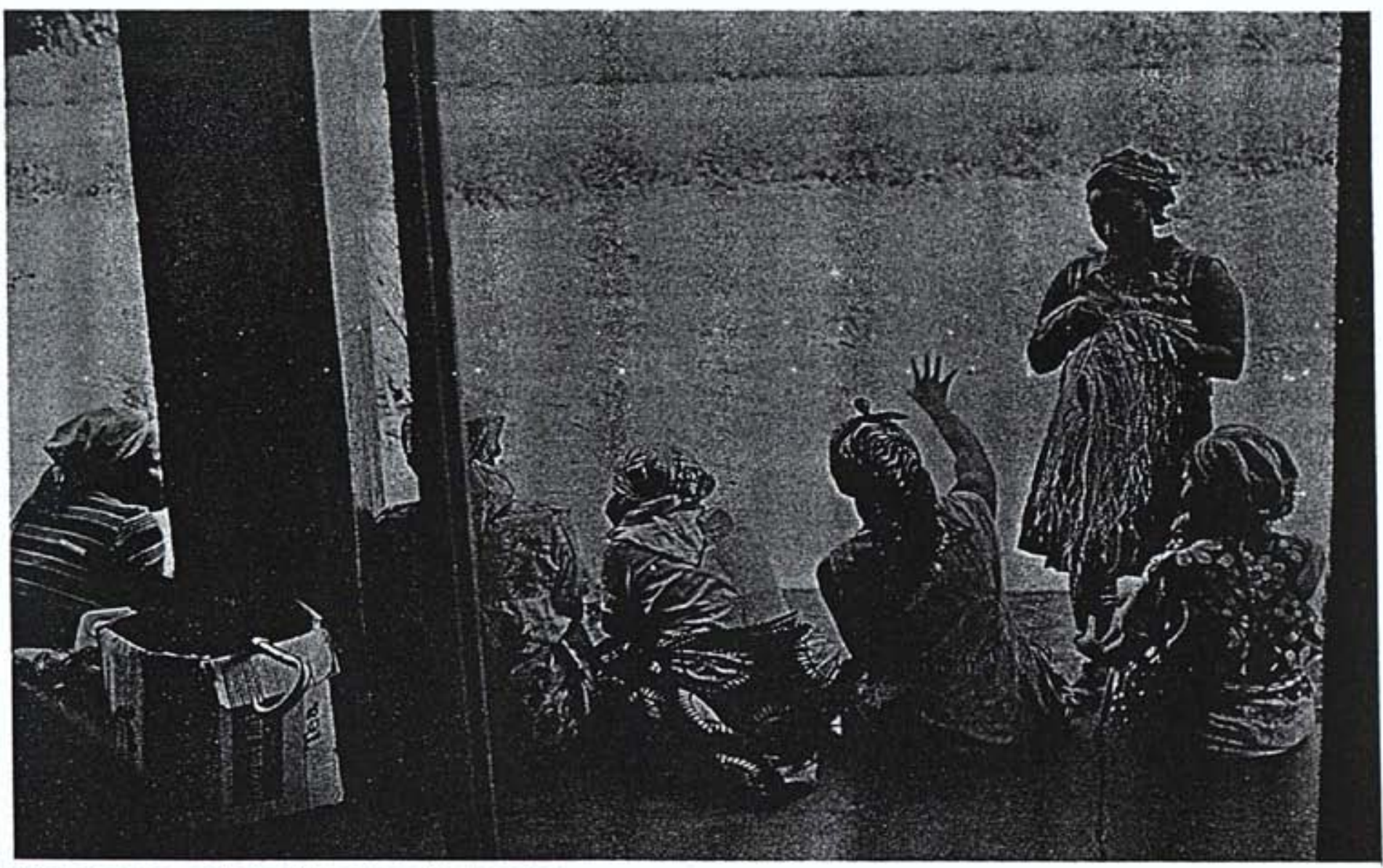

Women sitting and standing on shop's doorstep. 


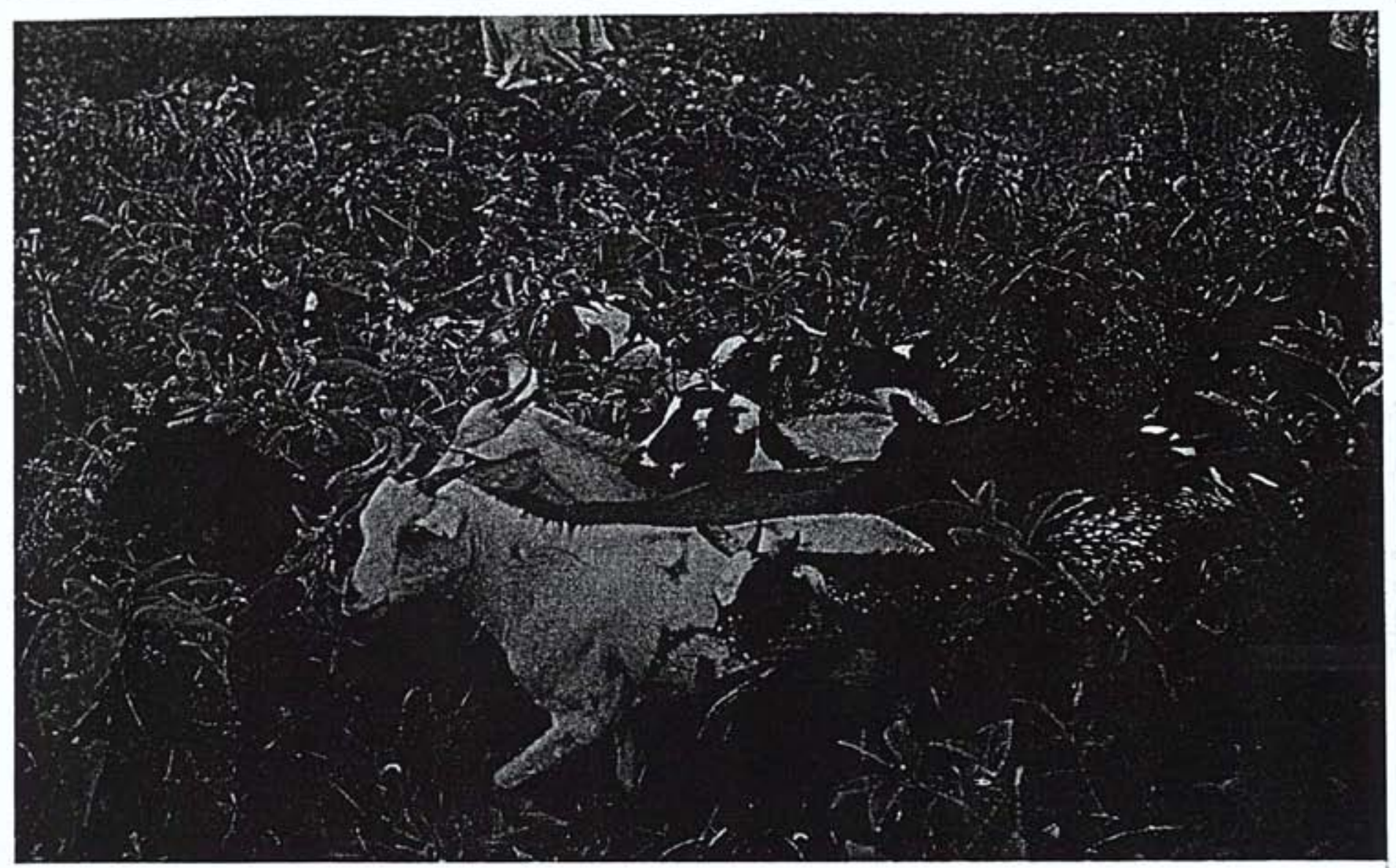

The goats.

Project Mraru Women Group of Maendeleo ya Wanawake

Village Kulele

Sublocation Mraru

Location Mbololo

Division Voi

District Taita/Taveta

Province Coast

Country Kenya

Mraru Women Group

Box 163

Voi, Kenya

Chairman Eva Mwaluma

Vice Chairman Polina Danson

Secretary Jamima Mahalon

Vice Secretary Dricilla Nginton

Treasurer Mary Fredrick
The Mraru Women Group, its official title, is an affiliate of the Maendeleo ya Wanawake Organization, whose national headquarters are at P.O. Box 44412, Nairobi, Kenya.

For general information about women's groups in Kenya write to:

Women's Bureau

Ministry of Housing and Social Services

P.O. Box 30276

Nairobi, Kenya

or

National Council of Women of Kenya

P.O. Box 43741

Nairobi, Kenya 


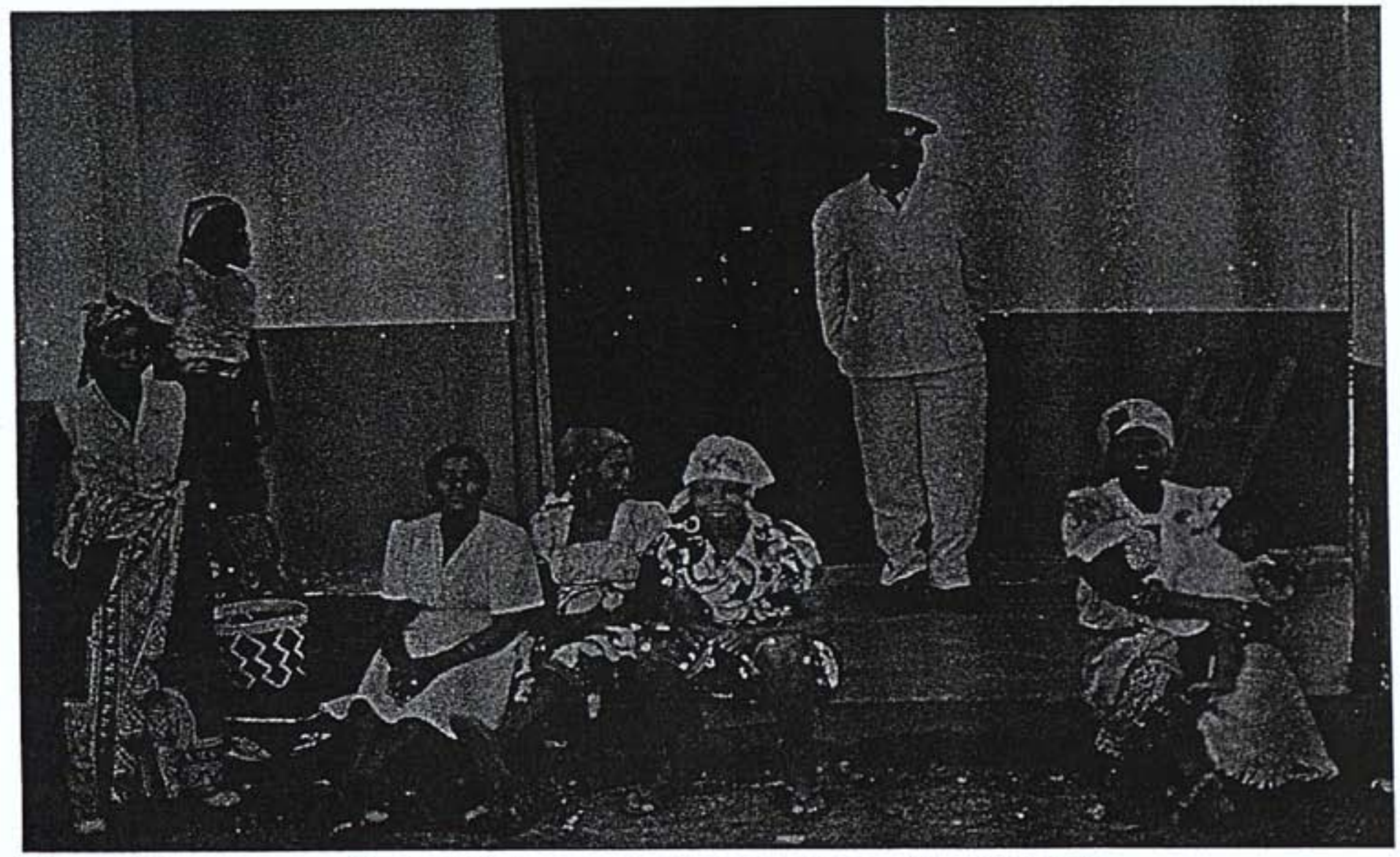

Women sitting on stoop, assistant chief in doorway of classroom;sewing machine visible inside. 


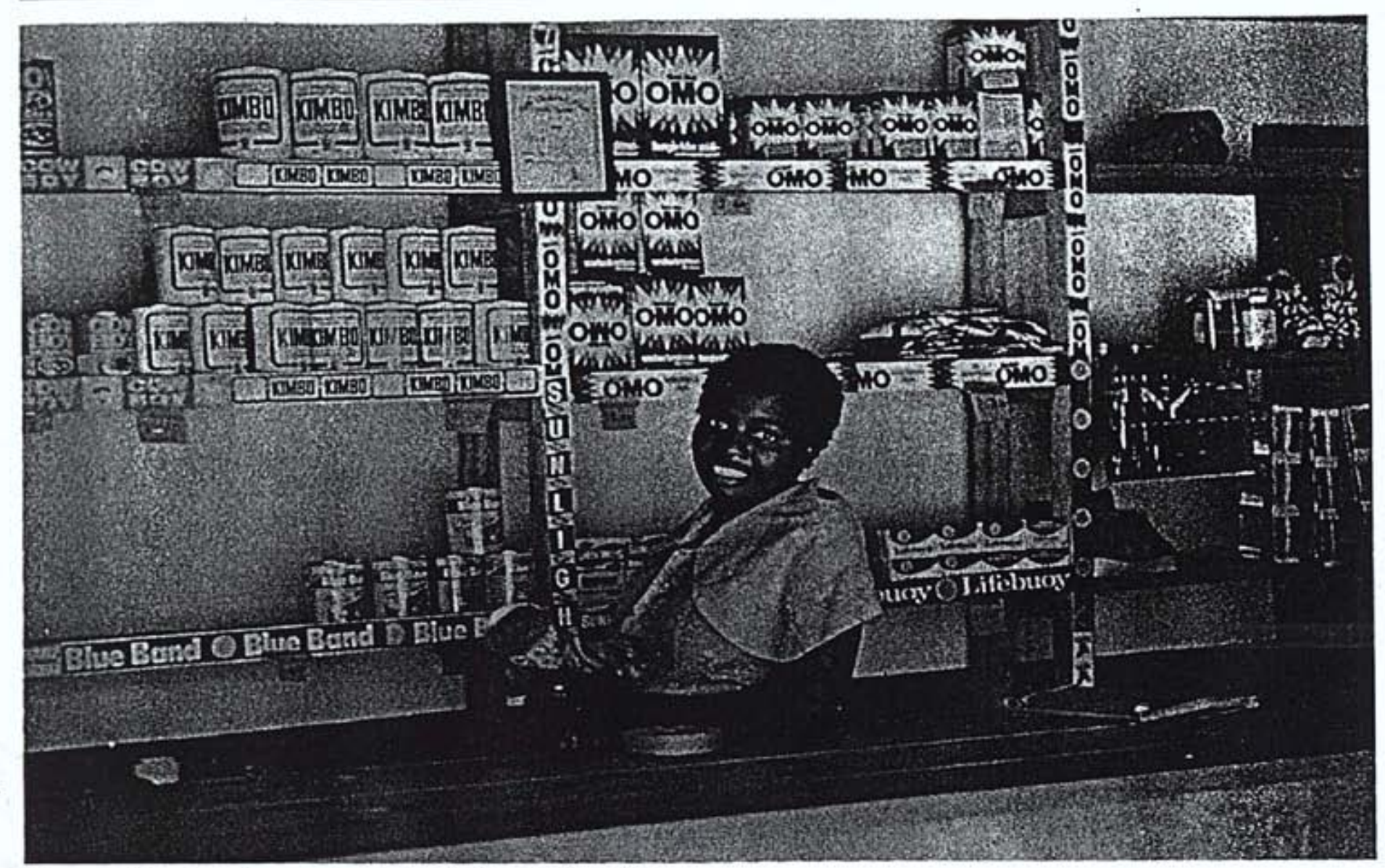

Elina and the shop. As members see it, "the duka is the child of the bus." 
Design Three to Make Ready Graphics

Typography Alphabette

Photography Jill Kneerim

Printing Tartan Executive Services

We invite your comments and your ideas for projects which might be included in future editions of SEEDS. If you would like additional copies of this issue or would like to be included on the SEEDS mailing list, please write to:

Ann Leonard, Editor

SEEDS

P.O. Box 3923

Grand Central Station

New York, New York 10017 U.S.A. 